\title{
BREVES REFLEXIONES SOBRE LA DIVISIÓN DE PODERES Y LA ADMINISTRACIÓN DE JUSTICIA EN ESPAÑA DURANTE EL SIGLO XIX
}

\section{BRIEF REFLECTIONS ON THE DIVISION OF POWERS AND THE ADMINISTRATION OF JUSTICE IN SPAIN DURING THE 19TH CENTURY}

\author{
Pedro Ortego Gil \\ Universidad de Santiago de Compostela
}

\begin{abstract}
Sumario: I. PLANTEAMIENTO.- II. PREVALENCIA DEL EJECUTIVO SOBRE EL LEGISLATIVO.- III. PODER EJECUTIVO Y POTESTAD JUDICIAL.- IV. LA FALLIDA CONSTRUCCIÓN ORGÁNICA DEL PODER JUDICIAL.- V. LA OPORTUNIDAD DE REVISIONES CRITTICAS.
\end{abstract}

Resumen: La pretendida división de poderes que recogieron los textos constitucionales españoles decimonónicos contrasta con la realidad. La prevalencia del ejecutivo en los procedimientos legislativos de iniciativa y delegación y el continuo empleo de disposiciones infralegales, le permitió, en el ámbito judicial, asumir la redacción de los textos por los cuales se reguló el enjuiciamiento civil y el penal, asi como controlar el estatuto de jueces y magistrados. Estos fueron considerados empleados públicos, sometidos al Ministerio de Gracia y Justicia, de modo que, en realidad, los tribunales no constituyeron en lo orgánico ningún poder al estar sujetos al ejecutivo cualquiera que fuera su ideología-, mientras que en lo funcional sí desempeñaron la potestad de aplicar las leyes en los juicios civiles y criminales con notable independencia.

\begin{abstract}
The alleged division of powers that is reflected in the Spanish constitutional documents of the nineteenth-century contrasts with reality. The prevalence of the executive in the legislative procedures of the initiative and the delegation and the continuous use of the infralegal provisions, permitted, in the judicial sphere, assuming the writing of the texts by which the civil and criminal prosecution was regulated, as well as controlling the judges and magistrates. These were considered public employees, that are subject to the Ministry of Grace and Justice, so that, in reality, the courts did not constitute in the organic any power as to be subject to the executive, whatever their ideology was, while functionally they executed the power to apply the laws in civil and criminal trials with remarkable independence.
\end{abstract}

Palabras clave: División de poderes, Administración de Justicia, Potestad judicial. 
Key Words: Division of powers, Justice administration, Judicial power.

\section{PLANTEAMIENTO}

Estas breves reflexiones giran sobre la realidad que muestra la vida politica y jurídica de la España decimonónica en cuanto a la pretendida división de poderes, quizá mejor de potestades, y descubrir, de paso, la querencia natural de los politicos contemporáneos a perpetuar vicios ${ }^{1}$.

Hace varios lustros, en una charla entre profesores, un viejo catedrático de la Universidad de Santiago de Compostela afirmaba que, en realidad, no hay tres poderes, sino uno y medio. Detrás de esta afirmación hay más de visión empírica que de teoria politica. En la actualidad los partidos politicos no buscan ganar las elecciones y obtener una mayoria parlamentaria. Su fin verdadero y prevalente es alcanzar el ejecutivo, más concretamente su presidencia. Desde él proyectarán su actuación al ámbito legislativo mediante la imposición de las actividades y decisiones del grupo parlamentario que le apoye. Sus proyectos de ley serán aprobados -si interesa- por esa misma mayoría sin apenas modificaciones. Su contenido estará destinado a fijar los instrumentos de control de la actividad, entre otros, de jueces y tribunales mediante la regulación tanto por ley como por decreto en asuntos que van desde los requisitos para acceder a la carrera judicial, los traslados, los ascensos o las retribuciones hasta sus órganos de gobierno. Ejemplos no faltan.

La situación es más compleja cuando no se obtienen mayorias absolutas o al menos suficientes. Entra, entonces, la negociación politica, que matiza las pretensiones del poder ejecutivo, aunque siempre le queda la iniciativa legislativa más técnica y factible de prosperar. No puede ocultarse que también se halle interesado en impedir cualesquiera iniciativas parlamentarias que busquen restringir o privarle de sus atribuciones. Incluso, mientras no se aprueben las leyes y exista una necesidad de regular determinadas situaciones, el Gobierno argumentará tal carencia y expondrá la urgencia para verificar mediante decreto lo que, en una situación de normalidad constitucional, debería regularse en sede legal.

Estas situaciones actuales no son nuevas. Es fácil comprobar cómo fueron planteándose durante el siglo XIX y, lo más interesante, reiterándose. En España, además, los problemas derivados de tres guerras civiles, los habituales golpes de gobierno, la existencia de poderosas facciones, primero, dentro de los grupos

\footnotetext{
${ }^{1}$ Estas páginas constituyen la versión ampliada de la exposición que realicé en la sesión de homenaje a José Manual Pérez-Prendes que, bajo el título "Cortes y parlamentos", se desarrolló en la Facultad de Derecho de la Universidad de Lisboa el 12 de octubre de 2018. José Manuel Pérez-Prendes fue, sin duda, un historiador del Derecho insatisfecho por su continúa avidez en aprender siempre un poco más. Un aprendizaje critico consigo mismo y con la historiografia que abordaba la materia jurídica. No se conformaba con lo que él u otros habían afirmado a partir de la investigación histórica. Reflexionaba sobre todo para encontrar nuevas perspectivas, vacios interpretativos y posibilidades de ampliar los horizontes de las investigaciones iurishistóricas. Opiniones que pueden apreciarse en su trabajo "Los relojeros del Derecho", Anuario Jurídico y Económico Escurialense, n 45, 2012, pp. 21-90.
} 
ideológicos y, más tarde, en el seno de los partidos políticos ${ }^{2}$, dio lugar a continuas alteraciones sociopoliticas con sus consabidos cambios de gabinete, cierres abruptos de las legislaturas, la formación de aparentes mayorias parlamentarias, modificaciones normativas sin respeto al principio constitucional de legalidad, etc.

Ante las dificultades para poder aprobar leyes que regularan aspectos sustanciales de la administración de justicia, tanto en su orientación orgánica como en la procedimental, se sucedieron mayoritariamente disposiciones con rango de real decreto u orden $\mathrm{real}^{3}$. Más allá de la consideración ideológica de raigambre francesa según la cual el poder judicial era una apéndice del ejecutivo ${ }^{4}$, fueron los sucesivos gobiernos los que intervinieron sobre el estatuto de los jueces, regularon los requisitos de acceso a la Judicatura, permitieron y ratificaron a los jueces nombrados en momentos de gran alteración política, convocaron o retardaron las oposiciones una vez que se instauró legalmente este procedimiento para acceder a la Judicatura, tuvieron entre sus atribuciones el traslado y ascenso de los juzgadores -con o sin su asentimiento-, controlaron a unos jueces que, en cuanto empleados públicos, dependian constitucionalmente del nombramiento regio ${ }^{5}$, los que, en fin, regularon e introdujeron cambios

2 Un repaso fundamental para comprender su génesis y su evolución en España durante la primera mitad del siglo XIX en Ignacio Fernández Sarasola, "Los partidos politicos en el pensamiento español (1783-1855)", Historia Constitucional, $\mathrm{n}^{\circ} 1$ (2000), accesible en la dirección electrónica http://www.historiaconstitucional.com/index.php/ historiaconstitucional/article/view/108; y con mayor amplitud en Los partidos politicos en el pensamiento español: de la Ilustración a nuestros dias, Marcial Pons, Madrid, 2009.

3 Ha insistido en este carácter infralegal, Marta Lorente Sariñena, "Reglamento provisional y administración de justicia (1833-1838). Reflexiones para una historia de la justicia decimonónica", en Johannes-Michael Scholz (coord.), El tercer poder. Hacia una comprensión histórica de la justicia contemporánea en España, Vittorio Klostermann, Frankfurt am Main, 1992, pp. 215-296; y, “Justicia desconstitucionalizada: España, 1834-1868”, Cuadernos de Derecho Judicial, n 6, 2006, pp. 243-286.

${ }^{4}$ Puede servir de ejemplo la discusión en el Congreso de los Diputados el 3 de diciembre de 1844 y, singularmente, la intervención de Alejandro Oliván a propósito del proyecto constitucional (Diario de las sesiones del Congreso de los Diputados en la legislatura de 1844 a 1845, Imprenta Nacional, Madrid, 1844, tomo I, n 46, pp. 440-443). En iguales términos, se sostendrá que "el orden judicial es la rama del poder ejecutivo que versa sobre las cosas que dependen del derecho civil latamente considerado, esto es, del derecho que arregla los intereses respectivos de los ciudadanos entre sí, o de los intereses privados con relación al Estado", palabras de Florencio García Goyena y Joaquin Aguirre, Febrero o librería de jueces, abogados y escribanos, Gaspar y Roig, Madrid, 1852, $4^{\text {a }}$ ed., tomo III, p. 398. El senador Florencio Rodriguez Vaamonde mantendría la misma idea pocos años después: "Yo creo que no es poder, yo creo que eso no es más que una rama del poder ejecutivo, que se ejerce por medio de funcionarios independientes e inamovibles para dar esas garantias a las personas que tienen interés en la Administración de justicia" (Diario de las sesiones de las Cortes. Senado. Legislatura 1858-1860, Imprenta Nacional, Madrid, 1859, tomo I, n 36 , p. 487, sesión de 11 de febrero de 1859).

${ }^{5}$ Aunque no es el único trabajo en que incide en este asunto, es referencia, Julia Solla Sastre, La discreta práctica de la disciplina. La construcción de las categorias de responsabilidad judicial en España, 1834-1870, Congreso de los Diputados, Madrid, 2011. Más recientemente pueden consultarse los trabajos de Pedro Ortego Gil, "Control y descontrol ministerial sobre jueces y juzgados de primera instancia (1834-1902)"; $\mathrm{M}^{\mathrm{a}}$. Teresa Bouzada Gil, "La responsabilidad disciplinaria de los jueces en Galicia según los asientos de los Libros de Registro de la Audiencia de La Coruña: 1868-1900"; y Alicia Duñaiturria Laguarda, “¿Cómo se controló a los jueces en el siglo XIX? Cuatro formas de reproches a la luz de los expedientes personales”, en José Sánchez-Arcilla 
sustantivos en el procedimiento civil y en el criminal ${ }^{6}$, determinando incluso por vía de decreto qué procesos podian recurrirse ante el Tribunal Supremo ${ }^{7}$. Circunstancias que no solo se aprecian en España ${ }^{8}$.

Constitucionalmente no podía ser de otra manera. El art. 47 de la Constitución (progresista) de 1837, dispuso que, además de las prerrogativas que

(coord.), Control y responsabilidad de los jueces (Siglos XVI-XXI), Dykinson, Madrid, 2017, pp. 159229, 231-319 y 346-397, respectivamente. Centrado en el control ministerial sobre los jueces de primera instancia con relación a sus nombramientos, ascensos, traslados y cesantías, Pedro Ortego Gil, Inamovilidad, interinidad e inestabilidad. El control ministerial sobre los jueces en el siglo XIX, Universidad Complutense. Servicio de publicaciones de la Facultad de Derecho, Madrid, 2018.

${ }^{6}$ Valga, como muestra de esta justificación la llamada Instrucción del marqués de Gerona: "El Gobierno, a quien está confiada la ejecución de las leyes en todos los ramos de la administración pública, no debe, no puede tolerar que costumbres abusivas se sobrepongan a su espíritu: y no translimita ciertamente sus facultades cuando dirigido por una recta intención, sin pagar tributo a teorias peligrosas, antes bien aceptando lo existente como punto más seguro de partida, respetando las bases orgánicas de nuestras instituciones jurídicas, las atribuciones de los tribunales, el orden jerárquico de su potestad, y las formas esenciales del procedimiento legalmente establecido, aspira únicamente a regularizar la tramitación por medio de instrucciones y reglamentos que la descarguen de superfluidades ilegales o extralegales, que le den unidad y cohesión donde hoy presenta la imagen del caos, y la pongan por último en armonía con los principios saludables proclamados por nuestras instituciones politicas... La reforma, si V. M. se digna aprobarla, está reducida, por ahora, a una instrucción para la tramitación civil, destinada a servir de saludable tránsito a las innovaciones futuras, y de poderoso calmante para los males presentes... Hombre de ley el consejero que suscribe, respeta como el que más los fueros del Parlamento; más en su larga carrera de magistrado y jurisperito ha tocado muy de cerca los achaques habituales de nuestra administración de justicia; ha oído los incesantes clamores de las víctimas, y tiene la íntima persuasión de que grava su conciencia de hombre público si, pudiendo, dilata por un solo día el aplicar al mal algún remedio. No puede temer el fallo de un Parlamento español el ministro que se apresura a satisfacer una necesidad por todos sentida y por todos reclamada; y anticipa de este modo un beneficio inmenso al pueblo confiado al maternal cuidado de V. M." (Real decreto de 30 de septiembre de 1853, Gaceta de Madrid de 4 de octubre). Las cursivas son mias.

${ }^{7}$ Sin detallar su importante número, puede servir de lectura el Real Decreto de 4 de noviembre de 1838 referido a los recursos de nulidad ante el Tribunal Supremo: "Deseando poner término al entorpecimiento que se experimenta en la administración de justicia por no haberse aún decidido varias consultas pendientes sobre recursos de segunda suplicación e injusticia notoria, ni declarado los trámites de enjuiciamiento de los recursos de nulidad contra los fallos de las Audiencias y del Tribunal de Guerra y Marina, en uso de la autorización que concedió a mi Gobierno la ley de 21 de julio último, he venido en decretar lo siguiente...", admitiéndolo en procesos civiles, pero rechazándolo en causas criminales y pleitos posesorios y ejecutivos (Gaceta de Madrid de 6 de noviembre). La ley mencionada permitía al Gobierno reformar el Reglamento provisional para la administración de justicia y las disposiciones del titulo $\mathrm{V}$ de la Constitución de 1812, autorizándole "para reunir en una sola instrucción las reglas a que ha de sujetarse la sustanciación de toda clase de juicios, así civiles como criminales". El art. 2 determinó que "los tribunales y juzgados ordinarios observarán la instrucción que el Gobierno formare mientras que por una ley no se disponga otra cosa". El proyecto, con fecha 7 de junio, fue presentado al Congreso en la sesión de igual fecha (Diario de las sesiones de Cortes. Congreso de los Diputados. Legislatura 1837, J.A. García, Madrid, 1874, tomo IV, $\mathrm{n}^{\circ} 167$, apéndice segundo). El texto fue aprobado en la sesión del día 22. Ley que no me consta sancionada por la reina, a pesar de haberse aprobado también en el Senado el día 3 de julio, quizá por la clausura de las Cortes.

8 Para la evolución portuguesa se hace imprescindible la consulta de Isabel Graes, O poder e a justiça em Portugal no século XIX, AAFDL, Lisboa, 2014, pp. 876-890. Para España, es preciso destacar la exposición global de Miguel Ángel Aparicio, El status del Poder judicial en el constitucionalismo español (1808-1936), Universitat de Barcelona, Barcelona, 1995. 
la Constitución señalaba a la reina, le correspondia, entre otras atribuciones: "Cuidar de que en todo el reino se administre pronta y cumplidamente la justicia". La primera Constitución democrática, la de 1869, volvia a insistir en su art. 73 en que "además de las facultades necesarias para la ejecución de las leyes, corresponde al Rey: ... 5. Cuidar de que en todo el Reino se administre pronta y cumplida justicia”. Si esto decían los textos constitucionales progresistas, no es preciso reproducir lo que manifestaban las constituciones moderadas. ¿Rémora del pasado? Sí, pero también interés político de la Corona, entendiendo por tal y a imitación inglesa, el rey con su Gobierno o sus ministros responsables ${ }^{9}$. Adviértase que esta atribución no se encomendó a ningún órgano jurisdiccional, sino al propio rey.

El poder ejecutivo era, para algunos juristas, mucho más de lo que pudiera entenderse a primera vista, sobre todo cuando empiezan a distinguir en su seno un poder administrativo y un poder judicial, que tratan de presentar sobre bases de actuación diferenciadas. Para entender la defensa de esta postura hay que acudir a Francia, o más en concreto a la traducción española de la obra de Macarel y seguir la reiteración ${ }^{10}$, más allá de sus ideas, de sus propias palabras en los administrativistas españoles. Entre otros José Posada de Herrera quien, siguiendo al jurista francés, destacaba la importancia del legislativo en cuanto vértice de un triángulo en cuyas bases se situaba el ejecutivo -primeramente referido como administrativo- y el judicial, pero reconociendo que el primero no seria nada sino hubiese "un poder revestido de la fuerza bastante" para hacer ejecutar las leyes, al que se le daban "todas las atribuciones necesarias para vencer las dificultades que encontrasen en su marcha". Lo más interesante para la materia aquí abordada viene a continuación:

"Este poder se conoce en España con el nombre de poder ejecutivo, y como las leyes pueden referirse a los intereses del ciudadano particular o a los intereses de la sociedad en general, o a las relaciones de esta con el individuo, se divide el poder ejecutivo en dos brazos distintos: el uno encargado de los intereses generales de la sociedad que se llama poder ejecutivo, $y$ mejor dicho poder administrativo; el otro encargado del cumplimiento de las leyes civiles y de la resolución de las cuestiones que ocurren entre los particulares, que se llama poder judicial" 11.

\footnotetext{
9 Como muestra de esta concepción, según la cual la Corona es un entramado institucional, sirvan las palabras de Antonio Alcalá Galiano: "cuando digo S. M. hablo del Gobierno y sus agentes responsables" (Diarios de sesiones de Cortes. Estamento de procuradores. Legislatura 1834-1835, J.A. García, Madrid, 1867, tomo I, nº 66, sesión de 20 de octubre de 1834, p. 578).

10 Louis-Antoine Macarel, Elementos de Derecho politico, traducción de Félix Enciso Castrillón, Yenes, Madrid, 1838 (Éléments de Droit politique, Nève, Paris, 1833). Cabe repasar algunos de sus pasajes: "La ejecución de las leyes puede procurarse y obtenerse de dos modos: por vía de acción y de persuasión, o por vía de decisión o de fuerza, de donde resulta que el poder ejecutivo se divide en dos ramos, a saber: el que toma el nombre de administrativo, o sea de gobierno, y que es el verdadero poder ejecutivo, y el otro el que se nombra poder judicial" (tomo I, p. 36). Más delante afirmará que "se llaman jueces a los funcionarios a quienes está confiado este poder... El poder judicial es uno de los órganos del poder legislativo, y el que le pone en acción... Siendo el poder judicial uno de los ministros de la ley deben mostrarse los jueces como los primeros y más rígidos observadores de la ley" (idem, pp. 36 y 40).

11 José Posada de Herrera, Lecciones de administración, Establecimiento Tipográfico, Madrid, 1843, tomo I, p. 69. Lo que había expuesto poco antes Pedro Gómez de la Serna, Instituciones de Derecho administrativo español, Vicente de Lalama, Madrid, 1843, tomo I, p. 12. En la Gaceta de Madrid se
} 
Con independencia de los reparos que muestra a continuación sobre el cumplimiento de las órdenes del poder administrativo, insiste en el deslinde de competencias entre uno y otro, al manifestar que "se ve pues claramente que el rey puede asistir a las decisiones del poder administrativo, pero no a las del judicial". Esto es así porque se trataba de dos poderes "cuyo carácter es completamente opuesto y cuyas atribuciones no pueden reunirse en una sola mano sin un contrasentido" y, por supuesto, atendiendo a la naturaleza de sus funciones y a la garantía de la libertad, la seguridad y la propiedad de los ciudadanos. Una separación de fines y atribuciones que no se trasladaba a la configuración orgánica. Si al monarca correspondia nombrar y separar a todos los empleados de la administración, también él "es el que nombra todos los empleados en las funciones judiciales, de manera que en su origen estas dos clases de funcionarios tienen perfecta semejanza, aunque la una sea inamovible por su esencia, y la otra amovible por su naturaleza"12. La realidad mostraria, durante la mayor parte del siglo XIX, que unos y otros empleados públicos, al contrario de lo dispuesto en los textos constitucionales, fueron amovibles.

Afirmaciones que se fueron repitiendo apoyándose incluso en viejos conceptos en un momento en el que se estaba fraguando en España la jurisdicción administrativa y el deslinde competencial ${ }^{13}$.

reprodujeron palabras similares: "La necesidad de que el poder administrativo o ejecutivo se divida en dos brazos distintos para atender a todos los intereses y dirimir todas las contiendas. Forma el uno de estos brazos el poder administrativo, propiamente dicho, como encargado de los intereses generales de la sociedad; forma el otro el poder judicial que, encargado del cumplimiento de las leyes civiles, tiene la misión santa de administrar justicia y de resolver las cuestiones que hacen surgir entre los particulares la oscuridad, la mala fe, el encono o la desapoderada ambición" ("Estudios administrativos. De los poderes administrativo y legislativo", Gaceta de Madrid de 31 de mayo de 1844). Hallaremos afirmaciones más tajantes: "lo que regularmente se llama poder judicial, no es más que uno de los ramales del poder ejecutivo, una emanación suya, cuyo objeto es aplicar las leyes de arreglan los intereses de los particulares entre si”, con independencia de que su ejercicio no podia confundirse ni reunirse (Antonio Gil de Zárate, "Administración de los Tribunales contencioso-administrativos", Revista de Madrid, I, 1838, pp. 97-110, la cita en p. 100). El marqués de Tabuérniga (Juan Antonio de Padua Florán) llegó a proclamar en sede parlamentaria, y en una interesante sesión sobre esta materia, que "el poder judicial, y ruego a las Cortes no extrañen esta definición, no es más que un brazo del poder ejecutivo... La independencia dada a los tribunales, para sustraerlos de la dependencia del poder, no autoriza de manera alguna esa autonomia, su existencia pura y simplemente" (Diario de las sesiones de las Cortes Constituyentes. Legislatura 1854-1856, Imprenta Nacional, Madrid, 1856, tomo XIV, $\mathrm{n}^{\circ}$ 377, sesión de 9 de marzo de 1856, p. 8281).

12 José Posada de Herrera, Lecciones de administración, op. cit., pp. 82-85. Reproduzco algunos pasajes de un artículo, sin firma, publicado en el diario oficial: "Semejantes los funcionarios de ambos en deber al Monarca su nombramiento y su investidura, es de notar que el monarca puede ejercer por sí las funciones administrativas, y no puede mezclarse ni entrometerse de modo alguno en las judiciales, porque siendo el ministerio fiscal el representante del poder administrativo ante los tribunales, si el rey se sentara en los escaños de los jueces o influyese en sus sentencias, sería acusador y juez al propio tiempo, lo que es un absurdo" ("Estudios administrativos. De los poderes administrativo y judicial", Gaceta de Madrid de 14 de junio de 1844). Guarda bastante relación con la obra de Posada de Herrera, pero hay algunas diferencias sustanciales. Existe una importante variación entre el texto de la Gaceta de Madrid y el de las Lecciones de administración de Posada de Herrera, porque mientras en el aquel el ejecutivo aparece en primer lugar, en las segundas figura el legislativo, seguido del administrativo y el judicial. Quizá proceda de alguno de los discipulos que transcribieron dichas Lecciones.

${ }^{13}$ Con posterioridad recogería las ideas y palabras de Macarel al sostener que "el poder judicial y el poder administrativo tiene de común que ambos ejercen lo que se llama jurisdicción" (idem, 
Una teoría que encajaba en el sistema político de la Monarquía constitucional española, con unos y con otros. Estaba consolidada la separación de funciones, de manera que "la potestad de juzgar o aplicar la ley a las cuestiones de interés privado reside en el cuerpo de la Magistratura o en los tribunales del orden judicial", de lo que deriva que "la administración de justicia requiere una organización distinta y separada del poder administrativo". Independencia que se consagraba constitucionalmente a través de la inamovilidad de los jueces, una vez que ya había sido nombrados por el ministro de Gracia y Justicia para un juzgado o tribunal concreto, es decir, a posteriori:

"Se infiere claramente del texto constitucional que el rey es jefe supremo del poder ejecutivo, es decir, superior común de todas las autoridades así del orden administrativo como del judicial'14.

\section{PREVALENCIA DEL EJECUTIVO SOBRE EL LEGISLATIVO}

Por si tal no bastara y sin profundizar en la sujeción de tribunales y jueces a la ley, y por tanto a primera vista al poder legislativo, hay que destacar, no obstante, que la intervención ejercida sobre la actividad de este último por parte del ejecutivo, desemboca, en la realidad de los hechos, en un control que puede arrancar desde la redacción normativa emanada desde el Gobierno, o más concretamente del órgano integrado en el Ministerio de Gracia y Justicia que es la Comisión de códigos. Por tanto, sometimiento a la ley, sí, pero desde luego a una ley trazada en su mayor parte desde el ejecutivo.

En cualquier caso, una de las claves del proceso fue el innegable peso del poder ejecutivo, no en perspectiva de usurpación fáctica de potestades legislativas sino de asunción de atribuciones por vía de delegación o de inacción, y una lenta e imparable afirmación de la entidad del partidismo que se proyectó, a su vez, sobre jueces y magistrados particularmente a raiz de los cambios políticos, pacíficos o revolucionarios, con las consiguientes purgas de acuerdo con las adscripciones ideológicas.

p. 97). Lo que veremos también expuesto en el diario oficial: "El poder judicial como el administrativo no merecerian el pomposo nombre de poderes, ni lo serian en toda la significación de esta palabra, si no tuviesen la facultad de conocer y decidir de ciertos y determinados asuntos, o lo que es lo mismo, si no ejerciesen jurisdicción. De manera que jurisdicción es la facultad de conocer $y$ decidir de asuntos determinados. Dividese ésta en propia, delegada y prorrogada... prorrogada la que ejerce el poder judicial o el administrativo en su caso, en virtud del consentimiento tácito de los particulares que se presentan a ellos demandando la resolución de sus litigios" ("Estudios administrativos. De las competencias entre los poderes administrativo y judicial", Gaceta de Madrid de 9 de junio de 1844). Un jurisdiccionalismo que no se quedó en la etapa gaditana, estudiada e interpretada por Bartolomé Clavero, El orden de los poderes, El orden de los poderes. Historias constituyentes de la trinidad constitucional, Trotta, Madrid, 2007, pp. 3031 y 124-126. Fue más allá, al menos, en el plano doctrinal.

14 Manuel Colmeiro, Derecho administrativo español, 1858, Ángel Calleja, Madrid-Santiago, tomo I ( $2^{\text {a }}$ ed.), p. 41. Planteado en términos de independencia judicial a partir de textos legales y constitucionales y admitiendo la existencia del poder judicial, a la par que diferencia entre la postura teórica de progresistas y moderados, Jorge Pérez Alonso, "La independencia del Poder Judicial en la historia constitucional española", Historia constitucional. Revista Electrónica de Historia Constitucional, $n^{\circ} 19,2018$, pp. 47-87. 
A pesar del reconocimiento constitucional de los tres poderes, al comienzo de la primera década moderada se publicaba en el periódico oficial que, "el primero de todos por su imprescindible necesidad, por la fuerza y prontitud de su acción, no menos que por los grandes elementos que tiene para comunicarla y extenderla, es el poder ejecutivo o administrativo, pues tomamos estas dos voces como sinónimas". De manera que el legislativo "nada sería sin aquel, porque en vano los legisladores invertirian el tiempo en la discusión y elaboración de las leyes, si no existiese un poder que, revestido de una fuerza inmensa, se apoderase de las leyes escritas, las diese vida y las convirtiese en hechos", refiriéndose al ejecutivo ${ }^{15}$. Se omite, sin embargo, que la iniciativa legislativa residia, casi exclusivamente, en este último, por lo cual, desde el arranque de la tramitación legislativa hasta el posterior control sobre la ejecución de las leyes, era el único poder omnipresente. Por tanto, creo que el orden de formulación en la realidad politica española decimonónica no debería ser, al menos siempre, ley-gobiernojusticia, ${ }^{16}$ sino más bien gobierno-ley-justicia.

Entonces, ¿cuál fue el papel y la intervención de las Cortes? Con carácter general, puede decirse que muy limitado. Fueron varias la causas. Entre ellas podemos citar, en primer lugar, las delegaciones legislativas, bien a través de leyes de bases o de leyes de autorización ${ }^{17}$. Es habitual encontrar como fundamento de esta delegación legislativa la conveniencia de que las leyes voluminosas, entre las que figuran las reguladoras del enjuiciamiento civil y del criminal, fueran redactadas por técnicos ${ }^{18}$, por juristas que hoy llamariamos de reconocido

15 "Estudios administrativos. De los poderes administrativo y legislativo", Gaceta de Madrid de 31 de mayo de 1844. Sobre la autoria vid. nota 12.

16 Bartolomé Clavero, El orden de los poderes, p. 126.

17 Por ejemplo, Ley de 13 de mayo de 1855 autorizando al Gobierno para que ordene y compile las leyes y reglas del enjuiciamiento civil, con sujeción a las bases que se expresan (Gaceta de Madrid del dia 17). El R.D. de 22 de diciembre de 1872 es significativo: "Teniendo presente lo prescrito en la primera disposición transitoria de la Ley provisional sobre organización del poder judicial, a propuesta de mi ministro de Gracia y Justicia y oído el parecer del Consejo de Ministros, Vengo en decretar. Art. 1. La Ley provisional de enjuiciamiento criminal se publicará a continuación de este decreto, comenzará a regir desde el 15 de enero próximo... Art. 2. Sin perjuicio de lo dispuesto en el artículo anterior, Mi ministro de Gracia y Justicia presentará a las Cortes dicha Ley provisional de enjuiciamiento criminal para su discusión y aprobación definitiva" (Gaceta de Madrid de 24 de diciembre). No hubo lugar a tal presentación ni discusión. En este sentido, Carlos Garriga ha insistido también la gubernamentalización de la actividad parlamentaria decimonónica en la voz Gobierno inserta en Diccionario politico y social del siglo XIX español, Alianza, Madrid, 2002, pp. 335-338.

18 Como argumento contra de la autorización legislativa, sirva el discurso de Antonio María Fabié: "con unas bases, aunque fueran más detalladas y mucho más minuciosas que lo son las actuales, se podia hacer un número infinito de Códigos distintos, y por consiguiente, que en realidad se da por el Congreso al aprobar este proyecto de bases, poco menos que una autorización ciega, que una autorización amplia, absoluta y desnuda para hacer un Código como crea que es mejor el señor ministro de Gracia y Justicia; porque si bien a estas bases se le pone la condición de que se ha de oír a la sección correspondiente de la Comisión de Códigos, es claro que por esta fórmula, para todos los que son entendidos en materia de legislación y de administración, se significa que no tiene obligación de aceptar ni de someterse a las opiniones y fórmulas que esa sección de la Comisión de Códigos manifieste, en su proyecto de ley; y por lo tanto, es evidente que una vez oída, una vez explorada y formulado el proyecto de enjuiciamiento civil por la sección correspondiente de la Comisión general de Códigos, el señor ministro de Gracia y Justicia con esta autorización está plenamente en su derecho haciendo un proyecto de ley totalmente distinto y conforme solamente con su opinión, con su doctrina y con su manera de ver en estas gravisimas cuestiones". Al mismo tiempo apuntaba la conveniencia de que precediera la promulgación del código civil a la reforma del enjuiciamiento civil. La réplica llegó 
prestigio, con independencia de su adscripción ideológica, e integrados en la Comisión general de Codificación ${ }^{19}$; o que mientras las leyes politicas podían discutirse en las Cortes, no debía de hacerse lo mismo con las leyes técnicas ${ }^{20}$. Cierto, aunque las bases y la autorización se discutieran en el seno de la Cámaras. A falta de procedimientos parlamentarios iniciados o concluidos con éxito, tampoco deben olvidarse las importantes innovaciones que se produjeron en materia de procedimiento en 1835, 1838 o 1853 mediante un simple real decreto, con independencia de que existiera cierto consenso político sobre la necesidad de proceder a dictar nuevas regulaciones procedimentales que abreviaran plazos y trámites o completaran el régimen de recursos ${ }^{21}$, y reconociendo que no todos los males de la administración de justicia eran culpa de parlamentarios y jueces, sino más bien de leguleyos que vivian de los pleitos, como expuso la llamada Instrucción del marqués de Gerona de $1853^{22}$.

Las Cortes gaditanas, sin duda por las circunstancias en que desarrollaron su actividad, sí se preocuparon y discutieron acerca de la reforma de y en la administración de justicia, aunque centrada, por razones obvias, casi exclusivamente en la criminal. Era preciso romper con aspectos clave del sistema procesal propio del Antiguo Régimen ${ }^{23}$. Las Cortes creadas a partir de 1834 no mostraron dicho interés. De la lectura de los diarios de sesiones se desprende

del diputado Salvador de Albacete, para quien "en cuanto al sistema de autorizaciones, ciertamente que ha habido una época durante la cual en los Parlamentos se ha agitado mucho la cuestión de si eran o no convenientes, y si en tesis general debían rechazarse. Pero ya los hombres de todas las escuelas, lo mismo en el orden político que en lo que se refiere a los sistemas de legislación que han de constituir las leyes positivas, todos están conformes en que en estas grandes Asambleas no se pueden discutir estas cuestiones, si la frase me es lícita, por lo menudo, porque lo repugnan las condiciones especiales de estas reuniones o de estas colectividades deliberantes; porque lo repugna la índole técnica, especial, especialísima de todas estas leyes, y sobre todo las ley es que se refieren a la manera de hacer valer sus derechos en todo lo que no se relaciona más inmediatamente con lo que exige el gobierno del Estado; porque en este punto había gran peligro, más que peligro, la absoluta imposibilidad de hacer buenas leyes discutiéndolas en todos los detalles" (Diarios de sesiones de Cortes. Congreso de los Diputados. Legislatura 1879-1880, Viuda e hijos de J.A. Garcia, Madrid, 1880, tomo IX, pp. 4939 y 4941, sesión de 17 de junio de 1880).

19 Véase la aportación de Blanca Sáenz de Santamaria Gómez-Mampaso, Las comisiones de códigos durante el reinado de Isabel II (1843-1869), Congreso de los Diputados, Madrid, 2010.

20 Benito Gutiérrez lo aclaraba con referencia a los códigos y a la Ley de enjuiciamiento civil: "Los señores senadores saben perfectamente bien cuál es el valor convencional de esta palabra. Las leyes técnicas no se forman aquí... Que se tenga desconfianza de unos y de otros Gobiernos tratándose de determinadas leyes, se comprende bien, porque es dificil que leyes inspiradas en un espíritu o en un pensamiento politico inspiren la confianza u obtengan la aquiescencia de los adversarios del Gobierno; pero cuando se trata de leyes del género de la que nos ocupa, que no prepara siquiera el Gobierno, porque no es el encargado de hacerlas, y cuya redacción está encomendada a una Comisión compuesta de personas de cuya competencia se podrá dudar, pero de su imparcialidad, de su rectitud, de su justicia nunca" (Diarios de sesiones de las Cortes. Senado. Legislatura 1879-1880, Madrid, 1880, tomo III, sesión de 12 de abril de 1880, pp. 1521-1522).

21 Téngase en cuenta, entre otras muchas disposiciones gubernativas, el R.D. de 4 de noviembre de 1838 sobre el recurso de nulidad ante el Tribunal Supremo.

22 Carlos Tormo Camallonga, "El Derecho es la justicia de los hechos: A propósito de la Instrucción del Marqués de Gerona", Anuario de Historia del Derecho Español, n 81, 2011, pp. 873-920.

${ }^{23} \mathrm{Al}$ respecto, María Paz Alonso Romero, Orden procesal y garantías entre Antiguo Régimen y constitucionalismo gaditano, CEPC, Madrid, 2008. 
que, cuando se aborda la reforma del enjuiciamiento, se trata de una discusión académica -en ocasiones reproduciendo artículos de la prensa jurídica, o viceversa ${ }^{24}$ - pero alejada de los problemas que realmente acuciaban a los ciudadanos que reclamaban delante de la administración de justicia. Un debate teórico en el cual es dificil encontrar argumentos fácticos basados en la realidad procesal diaria de quienes pleiteaban en juzgados y tribunales ${ }^{25}$.

Salvo durante la etapa constitucional gaditana, en la cual las Cortes aprobaron el Reglamento para la Audiencias y juzgados de primera instancia octubre de 1812- y el Reglamento del Tribunal Supremo -marzo de 1814-, hubo que esperar más de medio siglo para que el conjunto de la estructura orgánica fuera regulado por ley, a pesar de encontrar en este camino numerosas propuestas para verificarlo. Ni siquiera los sustanciales cambios estructurales de $1834 / 1835$ se ejecutaron por ley, sino mediante reales decretos ${ }^{26}$. Y éste es, precisamente, uno de los aspectos clave en este relato. Porque a pesar del número de proyectos presentados para regular orgánicamente el que para unos era el poder judicial y, para otros, simplemente el orden judicial, la administración de justicia o los jueces y tribunales, ninguno salió adelante hasta 1870.

Hay otro punto que me interesaria resaltar pues, aun siendo marginal, explica en parte y nunca exclusivamente, algunas de las incoherencias e indefiniciones de los primeros momentos de la época constitucional. Me refiero al establecimiento de una estructura judicial nueva, con unos jueces y magistrados que incluso sufrieron cambios importantes, pero que continuaron con el embarazo de aplicar unos procedimientos de raigambre medieval y moderna, apenas modificados en aspectos puntuales hasta 1855 en el enjuiciamiento civil y hasta 1872 en el criminal27.

${ }^{24}$ El caso más notorio es del de Pedro Gómez de la Serna quien, además de ser catedrático de Derecho civil y prolífico autor en diferentes ramas jurídicas, perteneció a la Comisión de códigos, fue ministro de Gracia y Justicia y presidente del Tribunal Supremo. Sus intervenciones en el Congreso de los Diputados concuerdan con las opiniones que manifestó, entre otras, en la Revista General de Legislación y Jurisprudencia.

${ }^{25}$ A propósito de una modificación en el art. 941 de la Ley de enjuiciamiento civil, en la sesión de 6 de diciembre de 1872, se oyeron las siguientes palabras del senador Eugenio Díez: "Pues bien; por este proyecto, al que solo tenía título de acción ordinaria, se le da un título ejecutivo, y viceversa; y sabida es la diferencia que entre nosotros existe entre el juicio ejecutivo y el ordinario y yo pregunto: ¿a quién corresponde hacer declaraciones sobre los hechos acontecidos y sobre los contratos celebrados en virtud de las leyes preexistentes? ¿A los legisladores? No. ¿A los tribunales? Sí. Los legisladores miran al tiempo que está por venir; los juzgadores miran el tiempo que pasó; deciden las contiendas que se suscitan sobre los contratos y obligaciones celebrados con arreglo a las leyes. Los legisladores no dirimen las contiendas que se suscitan entre los particulares por la mala inteligencia de las leyes, no; esto corresponde a los tribunales. Ellos resuelven sobre todos los hechos acontecidos cuando se ponen en tela de juicio; si estos hechos muestran a los legisladores que las leyes tienen graves defectos, entonces procede reformarlas, hacer otras; pero no reconocer los hechos, no dar validez a los contratos celebrados y las obligaciones pactadas a la sombra de las leyes; eso no puede ser" (Diarios de sesiones de Cortes. Senado. Legislatura 1872-73, Madrid, 1873, tomo II, nº 56, p. 610).

${ }^{26}$ Reales decretos de 17 de octubre de 1835 que aprobó el Reglamento del Tribunal Supremo (Gaceta de Madrid de 26 de octubre), y de 19 de diciembre siguiente por el que se aprobaron las Ordenanzas de las Audiencias (Gaceta de Madrid de 31 de diciembre).

27 "Las Cortes Constituyentes han estado lejos de querer cambios radicales, impremeditados y violentos en nuestras leyes seculares... pero tampoco cerraron la entrada a las innovaciones 
Todas las Constituciones entre 1837 y 1876 se remitieron al desarrollo legislativo para regular, en mayor o menor medida, la estructura orgánica y el estatuto de jueces y tribunales sobre los principios que en ellas se fijaron, como el de inamovilidad ${ }^{28}$, aunque no faltó el texto constitucional que concedió amplio margen al Gobierno ${ }^{29}$. La cruda realidad, sin embargo, marchaba por otros caminos. Lo que debiera haber sido regulado por ley, lo fue casi en su totalidad durante decenios por decreto, y así lo denunció la oposición política... mientras era oposición. Los proyectos quedaron en simples manuscritos u hojas impresas de los diarios de sesiones de las Cortes.

Surge así la duda sobre el interés que tuvieron los sucesivos Gobiernos en concluir el procedimiento parlamentario de tales proyectos: ¿estaban realmente interesados, con independencia de su adscripción ideológica, en conseguir la aprobación de la ley orgánica que regulaba la Administración de justicia? En mi opinión y con carácter general, no. En este sentido, con la finalidad de regular la estructura judicial, se presentaron alrededor de una quincena de proyectos entre 1834 y 1868, algunos con muy poca diferencia temporal o en legislaturas consecutivas, sin que se llegaran a aprobar ${ }^{30}$. Dicho lo cual, también es preciso matizar que algún ministro de Gracia y Justicia persistió en la tarea.

Lo podemos plantear desde otra perspectiva. Con independencia de las circunstancias sociopoliticas existentes en cada momento a nivel nacional, y que provocaron la clausura de las Cortes en numerosas ocasiones, cabe preguntarse: ¿por qué cuando hubo en diferentes momentos mayorias políticas, o al menos ideológicas, holgadas en el Congreso y en el Senado no fue posible la aprobación de ningún proyecto orgánico? Resulta problemático dar una respuesta unívoca, y discutibles las concurrentes. Pudiera parecer que existió, en relación a la

prudentes y saludables, que la época hacía necesarias... por ello la Comisión no se ha abandonado a sistemas o teorías... Su misión era más científica, más práctica, más nacional: en los libros de nuestros pragmáticos, en las costumbres del foro debía escoger lo que la experiencia de los siglos recomendaba como bueno; pero sin que el respeto exagerado a lo antiguo, ni el empirismo curial de la actualidad, fuesen obstáculo a reformas oportunas", en Pedro Gómez de la Serna, Motivos de las variaciones principales que han introducido en los procedimientos la Ley de enjuiciamiento civil, Revista de Legislación, Madrid, 1857, pp. VII-XV. Una visión amplia y comprensiva en Enrique Álvarez Cora, La arquitectura de la justicia burguesa: una introducción al enjuiciamiento civil en el siglo XIX, CEPC, Madrid, 2002; y, "La evolución del enjuiciamiento en el siglo XIX", Anuario de Historia del Derecho Español, n 82, 2012, pp. 81-111.

${ }^{28} \mathrm{El}$ texto constitucional de 1837 disponía: "Art. 64. Las leyes determinarán los tribunales y juzgados que ha de haber, la organización de cada uno, sus facultades, el modo de ejercerlas, y las calidades que han de tener sus individuos. Art. 66. Ningún magistrado o juez podrá ser depuesto de su destino, temporal o perpetuo, sino por sentencia ejecutoriada; ni suspendido sino por auto judicial, o en virtud de orden del Rey, cuando este, con motivos fundados, le mande juzgar por el tribunal competente". Por su parte, la Constitución de 1876 dispuso: "Art. 78. Las leyes determinarán los Tribunales y Juzgados que ha de haber, la organización de cada uno, sus facultades, el modo de ejercerlas y las cualidades que han de tener sus individuos. Art. 80. Los magistrados y jueces serán inamovibles y no podrán ser depuestos, suspendidos ni trasladados, sino en los casos y en la forma que prescriba la ley orgánica de tribunales".

29 Constitución de 1869, disp. transitoria $2^{\text {a: }}$ "Hasta que, promulgada la ley orgánica de Tribunales, tengan cumplido efecto los artículos 94, 95, 96 y 97 de la Constitución, el Poder ejecutivo podrá dictar las disposiciones conducentes a su aplicación en la parte que sea posible".

${ }^{30}$ Referencias de todos ellos encontramos en Francisco Lasso Gaite, Crónica de la Codificación española. Organización judicial, Ministerio de Justicia, Madrid, 1998. 
pregunta, dejación, interesada o no, por parte de esas mayorias parlamentarias para aprobar algunas leyes, o al menos para ejercer un mayor control de las atribuciones infra y alegales asumidas unilateralmente por el poder ejecutivo, singularmente en todo cuanto afectó a los administradores de la Justicia, desde el juez de primera instancia de entrada hasta el magistrado del Tribunal Supremo. En otras palabras, hay que ver quién propone las leyes, quiénes y cómo las aprueban (con o sin enmiendas, con o sin mayorias), o las paralizan o las rechazan, y en qué condiciones o circunstancias sociales, políticas y económicas, para comprender mejor los intereses politicos por solucionar las rémoras normativas como las estudiadas en estas páginas.

Con unas Cortes controladas, la aprobación de los proyectos de ley o la delegación legislativa en los Gobiernos debían ser, en principio, simples trámites $^{31}$. De ahí que sea conveniente profundizar en las causas por las cuales, en determinados momentos en los que concurrieron circunstancias parlamentarias favorables, no quisieron los diferentes Consejos de ministros insistir vehementemente en la aprobación, bien de las bases, bien de un texto legislativo tendente a regular, por ejemplo, los elementos orgánicos del poder/orden judicial. Es cierto que, en unos casos, los bruscos cambios políticos o los habituales cierres de la legislatura y la consiguiente convocatoria de elecciones dieron al traste con los proyectos, pero en otros supuestos es estridente que una ley que afecta a la esencia misma del Estado no fuera aprobada ${ }^{32}$.

En ocasiones, sin embargo, la situación politica fue extremadamente propicia. Tras la Gloriosa Revolución de septiembre de 1868 se convocaron elecciones. Celebradas cuatro meses después, los progresistas alcanzaron una holgada mayoria, ratificada en las del año siguiente. Con este nuevo contexto se pudo sacar adelante el proyecto que se convertiría en la Ley orgánica provisional del poder judicial de $1870^{33}$. Pero, como se manifestaba explícitamente, con carácter provisorio -aunque en la realidad, centenario-, entre otras razones porque había sido aprobada por una mayoria ideológica, más que partidista ${ }^{34}$.

${ }^{31}$ Por este motivo, en mi opinión, debe matizarse esa idea de sujeción o sometimiento por parte de jueces y tribunales a la ley fruto del poder legislativo, en la que habitualmente se insiste. Entre otros trabajos, Bartolomé Clavero, "La gran innovación: Justicia de Estado y derecho de Constitución”, en Johannes-Michael Scholz (ed.), El Tercer Poder. Hacia una comprensión de la justicia contemporánea en España, Klostermann, Frankfurt am Main, 1992, pp. 169-188. Porque tanto en la iniciativa legislativa como en las disposiciones generales siempre hallaremos la acusada presencia del ejecutivo.

32 La descripción de estos proyectos, como se ha indicado, puede consultarse en Francisco Lasso, Crónica de la Codificación española. Organización judicial, op. cit.. Es significativa la acumulación de proyectos en el tránsito de la década de 1840 a la de 1850. Para la codificación procesal civil, del mismo autor, Crónica de la Codificación española. Procedimiento civil, Ministerio de Justicia, Madrid, 1998. El tomo tercero corresponde al enjuiciamiento criminal.

33 No fue la única que, afectando a la actividad judicial, se promulgó con igual fecha, pues se mandaron publicar, como provisionales, los proyectos de ley de matrimonio civil, reforma de la casación en lo civil, establecimiento del mismo recurso en lo criminal, y reformas consiguientes en el procedimiento criminal, y sobre el ejercicio de la gracia de indulto, declarando abolida la pena de argolla, disponiendo la observancia de varias reglas sobre los efectos civiles de la pena de interdicción, y dictando otras para la reversión al Estado de los oficios de la fe pública enajenados de la Corona, y para la provisión de las notarias (Gaceta de Madrid de 21 de junio de 1870).

34 Según, Miguel Martínez Cuadrado, Elecciones y partidos politicos en España 1868-1931, Taurus, Madrid, 1969, pp. 82-83, los monárquicos-democráticos, consiguieron 237 (de los cuales 
Sobre unas bases aprobadas por unas Cortes que se habian disuelto tras un levantamiento revolucionario y con un texto redactado por la Comisión de Codificación ${ }^{35}$, fue presentado por uno de los ministros más criticados por las contradicciones entre los textos normativos que defendió y lo que hizo en la práctica como titular de Gracia y Justicia. Me refiero a Eugenio Montero Ríos quien, después de varios intentos frustrados, lo consiguió, como se refleja en el refrendo ministerial a la sanción regia de la Ley orgánica provisional del poder judicial de 15 de septiembre de 1870. Texto que se ensalza, habitualmente, pero del que se omiten las dificultades y obstáculos reales que surgieron en su aplicación durante las dos primeras décadas de su vigencia, y que enlazan más con los males que pretendió resolver que con las soluciones que contenía.

Vinculado con lo expuesto, surge otro asunto imprescindible para comprender los avatares políticos y jurisdiccionales del siglo XIX. ¿Existió a lo largo de la etapa constitucional decimonónica el principio de legalidad? Formal o teóricamente, sí. ¿Se respetó desde el poder ejecutivo? No, porque primó el oportunismo político, particularmente tras los cambios revolucionarios o en las vueltas al régimen doctrinario ${ }^{36}$. Existen numerosas muestras de la abundante, cambiante y no siempre aplicada normativa centrada en el mundo judicial. No se trataria, por tanto, de insistir en el alcance de la correcta aplicación de la ley, sino y sobre todo de si al poder (ejecutivo) le interesaba aplicar y cómo los preceptos legales, lo que trasluce en la "avidez egoísta de ministros e parlamentares". De ahí la necesidad de conservar -lo que interesa-y emitir un "número desmesurado de diplomas"37. Esto explicaría cómo la ejecución de una ley es suspendida por una simple orden (España) o portaria (Portugal), decisión más explícita de hallar en numerosos decretos ${ }^{38}$.

Es conveniente insistir en otro aspecto complementario pero transcendental: estas leyes se aprueban por una mayoría parlamentaria, pudiendo mediar el consenso político. Lo cual no era óbice para manifestar, tras cualquier cambio de Gobierno, el rechazo a textos legales anteriores, cuyo cumplimiento no se respeta,

156 correspondian al Partido Progresista, y 81 de la Unión liberal), 20 de los demócratas), los republicanos, 85, y los carlistas, 20. Concuerda con estas cifras Pedro Pascual, Partidos politicos y constituciones en España, Fragua, Madrid, 1986, p. 151. Con lo cual, la coalición progresistaliberal alcanzaba una amplia mayoria.

35 Ley señalando bases para la organización de los Tribunales y para la formación de la ley de Enjuiciamiento criminal de 11 de abril de 1868 (Gaceta de Madrid de 12 de abril).

${ }^{36}$ Buen ejemplo es el art. 1 del primer decreto de 23 de enero de 1875, por el cual se deroga la disposición transitoria $6^{a}$ del título vigésimo tercero de la Ley orgánica provisional del poder judicial y, en su consecuencia, "se dejan sin efecto las declaraciones de inamovilidad otorgadas en virtud de ella a los magistrados y jueces" (Gaceta de Madrid de 24 de enero). Es decir, por vía reglamentaria y atendidas las circunstancias politicas del restablecimiento de la monarquía constitucional en España, se juzgó imprescindible desde el Gobierno proceder a una nueva purga ideológica entre jueces y magistrados.

37 Isabel Graes, O poder e a justiça em Portugal no século XIX, op. cit., p. XV.

38 Como muestra, el art. 2 del Decreto de 8 de mayo de 1873: "Las plazas de magistrados, con excepción de los de la Audiencia de Madrid, se proveerán confiriendo cuatro vacantes en la forma prevenida en el art. 133 de la Ley provisional, y una en un magistrado cesante de igual categoria. Para los efectos de esta disposición en los casos en que, según los artículos 133, 134 y 137 de la Ley provisional, tienen opción a estas plazas los presidentes de Tribunales de partido de ascenso, se entenderá en lugar de estos los jueces de término" (Gaceta de Madrid de 9 de mayo). 
se dejan de aplicar, se desconocen o, sencillamente, se vuelven a modificar. Sin restar importancia a la lentitud propia del procedimiento parlamentario, puesto que una vez aprobadas las leyes resulta más sencillo oponerse a su cumplimiento por la vía del decreto que proceder a su derogación siguiendo los cauces legislativos.

Como aspecto transcendente a lo que acabo de exponer, es preciso reseñar que los jueces de primera instancia, los más numerosos e inmediatos a las comunidades, fueron actores que coadyuvaron a la consecución de mayorias parlamentarias. Esto era asi, porque los jueces fueron funcionarios de nombramiento regio ${ }^{39}$, sujetos a los mandatos del Gobierno a través del Ministerio de Gracia y Justicia -incluso del Ministerio de la Gobernación o de lo Interior- y de las autoridades $u$ órganos de gobierno de las Audiencias Territoriales. Su influencia política en la comunidad y sus intervenciones directas o indirectas en las elecciones- son cruciales para determinar qué candidatos deben resultar electos o no. En suma, los jueces participaron, no como administradores de la justicia y sí como funcionarios del ejecutivo y/o agentes electorales del partido, en la configuración del poder legislativo ${ }^{40}$.

Por otra parte, las actas de los Cuerpos colegisladores traslucen el poco interés que mostraron diputados y senadores sobre cómo funcionaba la administración de la justicia -con minúscula- a los ciudadanos, los problemas generales que surgian o los obstáculos que se planteaban genéricamente en el proceso penal, y mucho menos en el civil. Tan solo cuando se discutieron las bases de las leyes de enjuiciamiento, la implantación del juicio oral o el jurado, los diarios de sesiones acapararon con relativa intensidad el debate sobre tales materias $^{41}$. Pero, de nuevo, las Cortes cedieron a la delegación legislativa en

${ }^{39}$ Luis E. Delgado del Rincón, "La configuración de la administración de justicia como parte de la administración pública durante el siglo XIX español (Análisis de algunos aspectos que influyeron en el proceso de burocratización de la justicia)", Revista de Estudios Politicos, n 98, 1997, pp. 221238. Julia Solla Sastre, "Justicia bajo Administración (1834-1868), en Marta Lorente Sariñena (coorda.), De justicia de jueces a justicia de leyes: hacia la España de 1870, Madrid, 2007, pp. 291324; y de la misma, "Finales como principios. Desmitificando la Ley orgánica de tribunales de 1870", Anuario de Historia del Derecho Español, n 77, 2007, pp. 427-466. Antonio Serrano González, "O juiz como categoria administrativa. Sobre a semântica estatal na Espanha do século XIX”, Penélope, n 6, 1991, pp. 73-91.

40 "No se puede oír sin escándalo, que los jueces han ido de puerta en puerta mendigando votos, que han recorrido los pueblos de su partido, con el mismo objeto, y que algunos han hecho viajes más largos, pasando de unas provincias a otras", afirmaba Álvaro Gómez Becerra, Observaciones sobre el estado del Poder Judicial en España, Colegio Nacional de Sordo-Mudos, Madrid, 1839, pp. 41-42.

${ }^{41}$ Baste leer el primer párrafo de la exposición de motivos del Proyecto de ley para la reforma de los procedimientos en los juicios civiles de 31 de enero de 1855: "La revisión de las leyes que ordenan los procedimientos de los juicios civiles es una necesidad generalmente reconocida. Formadas en diferentes épocas, y esparcidas en los códigos y colecciones legales de los seis últimos siglos, carecen de unidad, de precisión y de claridad, condiciones indispensables en todo buen sistema de procedimientos. Oscurecidas frecuentemente por vicios de la práctica; derogadas en parte por costumbres que han llegado a tener fuerza de ley; suplidas por las doctrinas de los tratadistas, y completadas por los usos del foro, inciertos y discordantes a las veces, presentan dificultades graves para su estudio, para su apreciación actual y para su aplicación. Esto seria por si solo motivo suficiente para revisarlas... Pero si bien esta obra es indispensable y urgente, no es fácil someterla en todos sus pormenores a las Cortes constituyentes. Leyes que tienen que ser forzosamente muy extensas, de carácter científico, técnico y práctico en su mayor parte, dificilmente pueden ser discutidas en una Asamblea numerosa. Esto nos 
favor del Gobierno, quien presentaria los proyectos redactados mayoritariamente por la Comisión de códigos que, no olvidemos, era una institución inserta en la estructura ministerial de Gracia y Justicia, aunque actuara con notable libertad ${ }^{42}$. El art. 4 de la Ley de bases de 11 de abril de 1868 puede servir de muestra: "El Gobierno dará cuenta a las Cortes de lo que hiciere, en observancia de lo prevenido en esta ley", puesto que el art. 1 disponia que "el Gobierno formará y pondrá en ejecución en su día una ley completa y definitiva de organización judicial y competencia de los Tribunales del fuero común", con arreglo a las bases que se enumeraban a continuación. Bases que contaban también con una sustancial salvedad en su art. 2: "Mientras no pueda ponerse en práctica la ley expresada en el artículo anterior, el Gobierno hará en la organización actual de los Tribunales las reformas que considere de mayor urgencia", de acuerdo con las reglas que se detallaban. Es decir, las Cortes declinaban la regulación de la organización judicial, con todo lo que ella conllevaba, en el poder ejecutivo, sin limitación cronológica, de manera que éste se encargaba de configurar desde el estatuto del juez a la estructura judicial, el procedimiento civil -pues la Ley de 1855 venía siendo remendada parcialmenteo el penal -que estaba por llegar-. Lo expuesto conduce a concluir que las Cortes decimonónicas españolas apenas mostraron interés por la realidad de la administración de justicia que se impartía a los ciudadanos.

De otra parte, la impronta politica de cuanto afectaba a los jueces y el alcance de su control orgánico fueron los puntos esenciales en los que se plantearon la mayor parte de las discusiones, no solo de proyectos legislativos, sino también con motivo de interpelaciones y preguntas. En estas interpelaciones parlamentarias acerca de la administración de justicia, lo que más se observa son las protestas por los traslados y cesantías con motivo de las alteraciones políticas o la convocatoria de elecciones. En el primer caso, los diputados que habían pertenecido a la mayoría y habian pasado a la oposición, protestaban por los cambios verificados en la titularidad de los juzgados, pues lo habitual es que se hubieran ordenado numerosas de cesantias; mientras que, en el segundo caso, protestaban, sobre todo, por los traslados. Es decir, no interesaba el correcto funcionamiento de los juzgados y tribunales, ni si resolvian más o menos procesos judiciales, tampoco si había lentitud y acumulación, etc. No, no interesaban estas cuestiones estrictamente procesales. Lo que interesaba eran las actividades

lo enseña la experiencia de todos los países y nuestra propia historia. Mas entre el examen minucioso de la ley y el extremo de una autorización dada al Gobierno vagamente y sin limites precisos y bien determinados, hay un medio prudente, que evita todas las dificultades. Consiste este en presentar a las Cortes las bases sobre que ha de fundarse la ley, bases que comprendan los puntos capitales del enjuiciamiento civil, y que puedan ser fácilmente discutidas y votadas por las Cortes. Tal es el medio que el Gobierno ha creído preferible" (Diario de las sesiones de las Cortes Constituyentes, tomo 3, n. 73, sesión de 1 de febrero de 1855, p. 1789, y apéndice $2^{\circ}$, pp. 1811-1812).

42 Como manifestación de su actuación, Esposición de los motivos y fundamentos de las bases para las leyes de organización de tribunales del fuero común y enjuiciamiento criminal, Ministerio de Gracia y Justicia, Madrid, 1863, donde al inicio ya se pone de manifiesto lo siguiente: "Conocidos son generalmente los vicios de la organización de nuestros tribunales. Hace ya cerca de diez años, que al pedir el Gobierno una autorización para reformar esta importante parte de nuestra legislación, decía a las Cortes, que la necesidad de mejorar lo existente, era un sentimiento casi unánime de la opinión pública... Pocos años después, el Gobierno, al presentar otro proyecto pidiendo autorización para formar una Ley de enjuiciamiento criminal, calificaba de conocidos los inconvenientes de los procedimientos que en la actualidad se siguen...". 
extraprocesales de los jueces, es decir, su intervención antes, durante y después de las elecciones, su ideologia, su influencia sobre la comunidad más cercana y, en consecuencia, el servicio al Gobierno de turno ${ }^{43}$.

Mientras los grupos ideológicos no estaban perfectamente estructurados dentro de las Cortes, el poder ejecutivo y sus iniciativas estaban más controladas. De ahí que, a pesar de la herencia del absolutismo monárquico, jueces y tribunales pudieron desenvolver su actividad con un mayor margen de maniobra. A medida que esos grupos ideológicos se fueron cohesionando y formando los gérmenes de los partidos políticos $\mathrm{y}$, más aún, cuando estos ya quedaron configurados como tales, el poder legislativo fue perdiendo importancia política y atribuciones. Esta evolución implicó que lo importante para esos bandos, facciones y partidos politicos fuera conseguir el poder ejecutivo, más concretamente la presidencia del Consejo de ministros, puesto que, a pesar del sistema de doble confianza, el alcanzar la mayoría en el parlamento solo era el instrumento para hacerse con el poder ejecutivo. De ahi que el poder legislativo se convirtiera, primero, en el principal medio para acceder al ejecutivo (la expresión autênticos serviçais submissos do poder es magnifica para apoyar esta idea ${ }^{44}$ ) y, en segundo lugar y más importante, para dominar desde este último todas las estructuras politicas del Reino, sometiéndolas a sus principios ideológicos a través de sus decisiones ejecutivas y proyectos legislativos.

\footnotetext{
${ }^{43}$ Podrian ponerse muchos ejemplos. Sirva alguno de ellos. El diputado Miguel de Roda, en la sesión del Congreso de los Diputados del 4 de enero de 1847, denunciaba que "muchos de los Sres. Diputados viven en la corte y se han olvidado de lo que pasa en los pueblos; yo he nacido en ellos, he vivido en ellos y sé lo que puede un juez de primera instancia, y diré que la coacción que ejerce es en mi juicio mayor, más fuerte y de más dificil resistencia que la de un jefe político o un intendente. La fuerza moral que tiene un juez sobre los electores es superior a la de cualquiera otra autoridad, porque en los pueblos no se cuidan mucho de cuestiones politicas, sino de cuestiones domésticas. Se pelea un vecino con otro, se forma causa, y se sobresee en ella o se eleva a plenario, se arruina o se salva una familia según la amistad que tiene con el juez; y claro es que siendo esto así, cuando un juez dice quiero esto, son muy pocos los electores que tienen fuerza bastante para resistírsele; y cuanto mayor sea el temor que tengan los electores de contrariar la voluntad de su juez, tanto mayor será la coacción y más clara la nulidad de la elección. Bien sé que es imposible probar la coacción hasta el punto que yo pretendo; pero por eso se dice que la coacción es moral, y yo que creo que la ha habido, solo pido a los Sres. Diputados que tengan presente qué es lo que vale un juez de primera instancia, y qué lo que vale un elector en esos pueblos. Vamos al terreno práctico. ¿Quiénes son los electores y qué ideas tienen? Son los mayores contribuyentes de los pueblos, labradores, hombres de ninguna instrucción o de muy poca, que la mayor parte no saben ni aun leer y escribir, y que todos los días necesitan al juez de primera instancia, porque dependen del alcalde en los negocios en que éste puede conocer, y en todos los demás del juez. ¡Y es cosa indiferente que un juez se presente con resolución a esos labradores inexpertos, sostenga cuestiones con ellos, les escriba las papeletas, o vea lo que los electores escriben en ellas? No, señores. Si el Congreso aprueba esta elección, lo hará sin duda con justicia, porque tendrá mejores datos que yo; pero creo que debe establecer como principio que el juez nunca se entrometa en las cuestiones electorales; que ese sacerdocio que debe ser tan elevado y tan puro no se emplee sino en administrar la justicia. El juez como particular podrá tener sus opiniones, pero como juez no debe más que administrar justicia; si hace otra cosa, falta a sus deberes, y el Gobierno que lo permite mina y socava la sociedad" (Diarios de sesiones de Cortes. Congreso de los Diputados. Legislatura de 1846 a 1847, Viuda e hijos de J.A. García, Madrid, 1877, tomo I, pp. 42-43).

${ }^{44}$ Expresión de Casal Ribeiro dedicada a los pares y diputados "filhos da urna gigante", frente a los de designación regia. Lo tomo de Isabel Graes, O poder e a justiça em Portugal no século XIX, op. cit., p. 49.
} 
Al margen de lo expuesto, cabe sostener, de igual manera, que no todo era de la exclusiva responsabilidad del Gobierno, pues el procedimiento parlamentario para la aprobación de las leyes, la presencia en los escaños de figuras claves del mundo jurídico español y, desde luego, las posiciones partidistas, cuando no de facciones, fueron obstáculos dificiles de salvar. Sin olvidar que los debates doctrinales acababan, en muchos casos, por no resolver las deficiencias que tenían que soportar los ciudadanos ${ }^{45}$.

El obstáculo principal, a mi juicio, era la lentitud en los cambios legislativos como se observa antes y después de la creación de la Comisión general de Codificación en 1843. Cuando sus textos llegan a los Cuerpos colegisladores, en ocasiones con modificaciones introducidas por mano ministerial, se detienen o pierden en los diarios de sesiones ${ }^{46}$. Redacciones extensas elaboradas sobre unas bases parlamentarias defendidas y aprobadas por juristas/politicos no siempre avezados en la práctica de la defensa de los intereses y derechos de los ciudadanos en juzgados y tribunales. Vacíos cubiertos en múltiples ocasiones por la vía infralegal, aunque no terminaran de resolverse los inconvenientes de su aplicación práctica.

Los jueces podian mitigar trámites, actuaciones, costes y agilizar el proceso. Los abogados, con intereses contrapuestos, dificilmente colaborarian para resolver con prontitud el procedimiento. Pero, ¿qué hacía el legislador? A mi juicio, relativamente poco. Sin duda contra tal lentitud se reaccionó puntualmente desde el Ministerio de Justicia, en concreto, con ocasión de la limitada vigencia de la, ya mencionada, Instrucción del marqués de Gerona, con independencia de las críticas manifestadas, en particular desde la abogacía, y no solo por el procedimiento normativo empleado. Fue preciso que ocurriera esta circunstancia para avanzar algo en materia de enjuiciamiento civil en 1855, aunque la herencia del ordo iudiciarius solemne resulta evidente. Es posible añadir otro factor nada desdeñable: la génesis de las leyes procesales está en el ejecutivo y su redacción en la Comisión de códigos, es decir, al margen del legislativo, por lo que la posterior iniciativa de las Cortes para su modificación era muy reducida o nula. En suma, o los cambios legislativos, en el ámbito que nos ocupa, eran propiciados desde el Gobierno o no se producian. Y, como sabemos, la adscripción politica y la composición del ejecutivo mudaba cada cierto tiempo, lo cual agravaba cualquier modificación legislativa.

Emilio Bravo mantenía, a mediados de la década de 1860, que en el Ministerio de Gracia y Justicia estaba todo por hacer. Recuérdese que en España a esas alturas de siglo solo se había aprobado la Ley de enjuiciamiento civil de 1855, mientras que el enjuiciamiento criminal seguia sujeto a pautas seculares, con algunos remiendos realizados por vía infralegal -si exceptuamos la Ley

45 "La práctica del sistema procesal -como afirma Álvarez Cora- se empeñó en una inconmensurable e incombustible resistencia a su sanación, de la que fueron -y son todaviaconocedores legislador y doctrina. Los vicios de la práctica procesal empujaban, continuamente, a retomar los problemas y a proponer nuevas modificaciones y revisiones. Sin reposo, el siglo se cerraria mareado en esta borrasca de reformas procesales, con sabor de insatisfacción" (La arquitectura de la justicia burguesa, op. cit., p. 47).

46 Lasso Gaite aludia a la multitud de proyectos, con especial referencia al enjuiciamiento civil, que "quedaron congelados en las secciones de las Cortes por distintos motivos, metajurídicos generalmente" (Crónica de la codificación española: Procedimiento civil, op. cit., p. 132). 
provisional reformada prescribiendo reglas para la aplicación del Código penal de 19 de marzo de $1848^{47}$, y los proyectos de configuración orgánica iban fracasando unos tras otros por la apatia parlamentaria, más que ministerial. Es decir, "en los demás centros de la alta Administración está casi todo hecho, en el de Gracia y Justicia está casi todo por hacer". De ahí que mantuviera, quizá con cierta visión ilusoria, que:

"Independientemente de los Códigos, obra de la comisión especial y de las Cortes, hay que fijar la organización judicial, y establecer sólidas bases para el ejercicio de la Justicia. En lo primero hay mucho hecho, y en breve quedará terminado todo; en lo segundo apenas se ha hecho nada"48.

En 1881 aún se pudo reducir un poco más la tramitación procedimental, pero no se eliminaron obstáculos e inconvenientes insalvables para los ciudadanos, como la lentitud o el coste ${ }^{49}$. Sin obviar que en las elecciones de 20 de abril de 1879 se había producido el consabido turno y surgido una nueva mayoria parlamentaria ${ }^{50}$, circunstancias que permitian aprobar la Ley de bases que daría lugar al texto que se convertiria en Ley de enjuiciamiento civil ${ }^{51}$. De los debates habidos en el Senado se desprende que el texto del proyecto de ley de enjuiciamiento civil estaba muy avanzado ${ }^{52}$, tanto que, conforme a él, se

47 Redactada también en virtud de delegación legislativa y, como se indica en su preámbulo, "por ahora, y hasta que se publiquen el Código de procedimientos y la Ley constitutiva de los tribunales, se observarán en la aplicación de las disposiciones del Código penal las reglas siguientes..." (Gaceta de Madrid de 28 de marzo de 1848).

48 De la administración de justicia Estrada, Diaz y López, Madrid, 1864, p. 475.

${ }^{49}$ Ley de autorización de 21 de junio de 1880, aprobada tras un paupérrimo debate en el Congreso, pues despachó la discusión del art. 1 del proyecto enviado por el Senado, en el que se enumeran las bases, los dias 17 y 18 de junio sin apenas debate, y sin él los otros dos preceptos por ser formularios (Diarios de las sesiones de Cortes. Congreso de los Diputados. Legislatura 1879-1880, Viuda e hijos de J.A. Garcia, Madrid, 1880, tomo IX, ns. 192 y 193, pp. 4934-4937, 4939-4950, 4967-4986 y apéndice $5^{\circ}$ del último). Contrasta con la dedicación que le había prestado la Cámara Alta, pues consumió en ella las sesiones de los dias 9, 10, 12, 13 y 14 de abril de 1880 (Diarios de las sesiones de Cortes. Senado. Legislatura 1879-1880, Madrid, 1880, tomo III, pp. 1470-1490, 1492-1509, 1512-1528, 15301554, 1564-1566). Un resumen completo de la tramitación en Francisco Lasso, Crónica de la Codificación española. Procedimiento civil, op. cit., pp. 132-142.

50 Partido Liberal Conservador, 293; Partido Constitucional, 56; Moderados y ultramontanos, 11; Partido Progresista Demócrata, 7; Independientes, 15; y no establecidos, 3. Estas cifras proceden de Miguel Martínez Cuadrado, Elecciones y partidos políticos en España 1868-1931, op. cit., p. 251. Por su parte, Pedro Pascual, Partidos politicos y constituciones en España, op. cit., p. 152, apunta el siguiente resultado: Partido conservador, 293; Constitucionales, 56; Moderados, 11; Posibilistas, 7; Progresistas, 7; vacantes e indefinidos, 18.

${ }^{51}$ Real Decreto de 3 de febrero de 1881 por el que se aprueba el proyecto de reforma de la Ley Enjuiciamiento civil: "Teniendo presente lo dispuesto en la Ley de 21 de junio del año próximo pasado, por la cual se autorizó a mi Gobierno para que, con sujeción a las bases en la misma comprendidas, y oyendo, como lo ha efectuado, a la sección correspondiente de la Comisión general de Codificación, procediera a reformar la Ley de Enjuiciamiento Civil, dictando las disposiciones convenientes para su planteamiento; conformándome con lo propuesto por el Ministerio de Gracia y Justicia, de acuerdo con el parecer de mi Consejo de Ministros, Vengo a decretar lo siguiente: Art. 1. Se aprueba el adjunto proyecto de reforma de Enjuiciamiento Civil, redactado con arreglo a las prescripciones y en virtud de la autorización concedida al Gobierno por la Ley de 21 de junio de 1880" (Gaceta de Madrid de 5 de febrero).

52 "El Gobierno -afirmaba Saturnino Álvarez Bugallal-, que siente no tenga terminado la Comisión el trabajo que se le ha encomendado, aunque el ministro que en este momento tiene la 
redactaron las bases y no al revés ${ }^{53}$. Por tanto, con alguna ligera modificación sobre el proyecto sustancial, cuya redacción se encontraba adelantada ${ }^{54}$, se elaboraron las bases, alterando lo que en lógica parlamentaria debería haber sido al contrario y donde el legislativo tiene una intervención secundaria, quizá matizada por el debate en el Senado, que no en el Congreso de los Diputados. Se advierte la conveniencia de hacer partícipe instrumental al legislativo en las leyes técnicas que debian promulgarse. El esclarecedor discurso de Benito Gutiérrez en el Senado a propósito del mecanismo de delegación legislativa para la promulgación de la Ley de enjuiciamiento civil, en cuanto ley considerada técnica, es muestra de ello:

"A nadie (se) le ocurrirá negar la conveniencia de que los poderes legislativos tomen parte en la formación de todas las leyes. Los legisladores, inspirándose en el pensamiento del Gobierno, identificándose con él, cuando él mismo ha tomado la iniciativa de la ley, claro es que habia de rodearla del prestigio y autoridad que tienen estos altos cuerpos, y es que esto se hace y se cumple"55.

La Ley de 1881 no contentó a buena parte de los prácticos desde su promulgación. En la década finisecular, un libro colectivo sobre la situación de la administración judicial contiene opiniones divergentes de diferentes juristas, aunque concordaban en los defectos de la regulación legal. En su prólogo Amat Furió afirmaba lo siguiente:

honra de dirigir la palabra al Senado tiene muy adelantado por su parte el principal para poder publicar la ley en breve, y que por no contar con el trabajo de la Comisión completamente ultimado ha querido ganar tiempo y obtener el concurso de los Cuerpos colegisladores para todas las soluciones concretas que se solicitan y están de acuerdo con la Comisión de Códigos, a fin de aprovechar el verano y organizar la ley y poner en práctica en el término más breve posible..." (Diarios de sesiones de las Cortes. Senado. Legislatura 1879-1880, Madrid, 1880, tomo III, sesión de 10 de abril de 1880, p. 1497).

53 Francisco Lasso, Crónica de la Codificación española. Procedimiento civil, op. cit., pp. 142149. Quien da cuenta que en ninguno de los borradores de las actas de la Comisión General de Codificación "se hizo mención a la redacción o acuerdo de formar estas bases", remitiéndose a José $\mathrm{M}^{a}$. Manresa para recoger que una vez discutidas y aprobadas las reformas en ésta, "formuló las bases que el Gobierno había de presentar a las Cortes, a fin de obtener la autorización necesaria para realizar la reforma". Concluyendo que, parece fundado que dicho jurista, en colaboración con el ministro, redactó tales bases, "que fueron pulidas antes de ser incluidas en el decreto citado" (nota 8, p. 133).

${ }^{54}$ Benito Gutiérrez al defender la delegación legislativa por medio de una ley de bases y no a través de una ley de autorización, señalaba lo siguiente: "La ley está hecha realmente, en cuanto es posible decir que está hecha una ley mientras no obtenga la aprobación de las Cortes. Está intentada y muy adelantada la reforma, no tanto que permita traerla como ley, porque seria menester proyectarla primero, y lo segundo, que aun cuando así no fuese, no se hubiera debido traerla. ¿Por qué? Porque no entrando en el pensamiento del Gobierno el traer la ley, era imposible que se ultimase sin que le diesen previamente aprobadas las bases que han de ser el punto de partida de la reforma... Pues no se ha presentado esa ley porque a ello se opone el sistema de bases, porque para eso habria sido necesario sustituir a ese procedimiento el procedimiento de las autorizaciones" (Diarios de sesiones de las Cortes. Senado. Legislatura 1879-1880, Madrid, 1880, tomo III, $\mathrm{n}^{\circ} 104$, sesión de 12 de abril de 1880, p. 1522).

55 Diarios de sesiones de las Cortes. Senado. Legislatura 1879-1880, Imprenta Nacional, Madrid, 1880, tomo III, sesión de 12 de abril de 1880, p. 1521. Razones que encontrarian su fundamento último en el art. 18 de la Constitución de 1876: "La potestad de hacer las leyes reside en las Cortes con el Rey". 
"Hallará aquí el lector opiniones encontradas acerca de la bondad de cada sistema procesal; encontrará partidarios de la apelación o de la instancia única; defensores del tribunal colegiado o del unipersonal; indicaciones diversas acerca de otros problemas de la organización y del procedimiento; tan solo ha habido unanimidad, pero unanimidad abrumadora, en la apreciación del actual estado de la administración de justicia. Todos la consideran defectuosa por unas u otras causas; todos eligen los colores más subidos de su paleta para pintar sus deplorables efectos; todos convienen en que el actual estado de cosas no puede continuar sin grave riesgo, y que la reforma no solo es necesaria, sino urgente; todos manifiestan pavor profundo ante la contingencia de que no llegue a realizarse en breve plazo. Ni una sola voz, ni una sola se ha levantado en favor del actual procedimiento; ni una sola ha intentado siquiera indicar que podamos continuar como hasta aqu’"56.

Se lamentaba, por tanto, de las leyes de enjuiciamiento de $1881^{57}$, sobre todo, y de 1882 cuando apenas habian transcurrido unos años. Lo que no pudo adivinar él, es que ambas leyes y pese a sus quejas continuaron vigentes más de un siglo. Encontraba una de las razones de esta situación en que la sociedad avanzaba con tal rapidez, que las dichas leyes -hija la de 1881 de la de 1855 y esta, a su vez, de la Tercera Partida de Alfonso X-iban quedando anquilosadas: un tren frente a una galera, en expresión de la época 58 . Un carro que, con reformas parciales, continuó su marcha hasta el año 2000.

Vicente Amat zanja estos antecedentes con una frase demoledora, cuyo contenido parece una herencia recibida hasta el presente:

"Triste es decirlo: hoy solo acude a los Tribunales el que no tiene otro remedio; se considera la intervención de la Justicia como una verdadera calamidad"59.

No sólo era un problema regulatorio de lo orgánico o lo procesal. Los juristas dedicados a la práctica apuntaban como mal endémico de la administración de justicia en España cierta dejación de diputados y senadores en resolver diferentes males denunciados desde la propia Judicatura, sobre los cuales todos estaban de acuerdo, pero que, tras los obstáculos presupuestarios, nadie fue capaz de resolver. En este sentido, son significativas estas palabras de José Víctor Brugada pronunciadas a finales de siglo, en las que también se enumeran los problemas presupuestarios, aspecto nada desdeñable:

56 La administración de justicia ante la opinión, Henrich y Compañia, Barcelona, 1890, pp. 7-8.

${ }^{57}$ Ley autorizando al Gobierno para que proceda a reformar y publicar la Ley de enjuiciamiento civil con sujeción a las bases que se determina, de 21 de junio de 1880: "Art. 1. Se autoriza al Gobierno de S.M. para que, oyendo a la sección correspondiente de la Comisión General de Codificación, proceda a reformar y publicar la Ley de enjuiciamiento civil, con sujeción a las bases siguientes... Art. 2. El Gobierno fijará el dia en que ha de principiar a regir la Ley de enjuiciamiento civil reformada, y determinará lo conveniente para que pueda aplicarse a los juicios pendientes, por lo menos, en las instancias sucesivas a la que se esté sustanciando. Art. 3. El Gobierno dará cuenta a las Cortes del uso que hiciere de esta autorización" (Gaceta de Madrid de 5 de febrero de 1881).

${ }^{58}$ La administración de justicia ante la opinión, op. cit., p. 9.

${ }^{59}$ En el prólogo de La administración de justicia ante la opinión, op. cit., p. 10. 
"No estaban en aquella época, como ahora, separados lo civil y lo criminal, en mi juzgado entraban seiscientas causas al año que habian de terminar por fallo, o por auto motivado de sobreseimiento; por consiguiente, unas dos causas diarias. Las cuestiones civiles innumerables; algunas de grandisima importancia; el solo despacho diario ocupaba cuatro horas; luego la visita de cárceles, la guardia y los sucesos imprevistos; una balumba tan inmensisima de atenciones que requería enorme tensión de espiritu para soportarla. Los jueces de carrera no se atrevian a representar sobre semejante absurda situación de cosas. Como yo tenía otra independencia, me atreví. Todos me dieron la razón; magistrados, diputados a Cortes, senadores y otros conspicuos personajes. Vióse claramente la necesidad de aumentar los juzgados, pero nada se hizo, porque cada uno presuponía un aumento en los gastos de veinte mil pesetas anuales, que no permitía el estado económico del Tesoro. Ese precario estado no impidió, sin embargo, ni ahora impide, ni jamás impedirá, que por atenciones de indole meramente politica, y de preponderancia de partido, se gasten miles y miles de pesetas que facilita el presupuesto forzosa $u$ holgadamente"60.

\section{PODER EJECUTIVO Y POTESTAD JUDICIAL}

El siglo XIX está presidido por una inquietante uniformidad ideológica a pesar de revoluciones, rupturas o cambios de Gabinete. En cualquier etapa se buscaba la unidad ideológica como la mejor forma de conseguir los objetivos de cada bando, facción o partido político ${ }^{61}$. Esta uniformidad es más fácil de comprobar allí donde el caciquismo podía influir más, esto es, en las elecciones municipales o parlamentarias. El Consejo de ministros se convertía en el "Gran elector". Pero también alli donde pudiera pensarse que habia más independencia, en los tribunales superiores, también alli el Gabinete o su ministro de Justicia y si me apuran, en realidad el director general encargado de los nombramientosextendia su prepotencia.

La pregunta que cabría hacerse acerca de la intervención, intensa, profunda, por parte del ejecutivo sobre la organización judicial, es: ¿Y para qué? La respuesta es compleja. No creo que fuera para tener amigos en el vértice de la pirámide judicial por si algún ministro pudiera llegar a ser enjuiciado. Ni siquiera por los pleitos civiles que cualquiera de ellos pudiera tener sobre su patrimonio. Tampoco parece que, al menos en ciertas etapas, el objetivo fuera inmiscuirse subrepticiamente en los litigios que pudiera mantener la Administración con los particulares, para lo cual se crearian los órganos jurisdiccionales pertinentes. En mi opinión, ese control era, sobre todo, ideológico y, por este motivo, el interés

${ }^{60}$ La administración de justicia ante la opinión, op. cit., p. 105.

61 "Administración de justicia, que no oculta el estado de dependencia en que viven por desgracia los tribunales con respecto, así de los partidos políticos, como del poder gubernamental. Y no es solo esta subordinación consecuencia espontánea de la organización dada a los poderes del Estado; es producto principalmente de las corruptelas en la aplicación de los principios; de las prácticas viciosas introducidas por los partidos; de la necesidad en que los gobierno están de aprovechar todos los medios a su alcance para procurarse defensa contra la enemiga de unos, contra la anárquica tendencia de otros", según Marcelo Martínez Alcubilla, Diccionario de la administración española. Compilación de la novisima legislación de España peninsular y ultramarina en todos los ramos de la administración pública, Arco de Santa Maria, Madrid, 1894, tomo 7, p. 501. 
bascula del lado de las atribuciones no procesales que asumieron los jueces de acuerdo con la legislación electoral -y las pautas enviadas desde la Corte- junto con los servicios politicos al Gobierno que los hubiera designado o al interés por medrar dentro del cursus honorum existente conforme a la meritocracia politica ${ }^{62}$.

No hay razón para pensar que los ministros de Gracia y Justicia estuvieran interesados en un pleito entre dos particulares sobre alguna tierra en Extremadura o en Galicia, por ejemplo. Es posible que pudiera mostrar más interés en cómo se desarrollaban los procesos y en los fallos de los jueces y tribunales en algunas causas criminales, sobre todo cuando afectaran a la tranquilidad pública y mucho más al sosiego político. Aún con todo, tampoco estarian interesados o se tratarian de inmiscuir en las sentencias del día a día de jueces y tribunales en asuntos ordinarios (no electorales), pues no eran, como se decía en la Edad Media, "hechos granados". Sí les podría interesar la unificación ideológica a través de quienes controlaban, en último término, la aplicación judicial de las leyes y disposiciones reglamentarias y de qué manera, así como el control del entorno social en que residian jueces y magistrados. Mientras que no se desvela preocupación desde el poder ejecutivo -sin distinción de ideologíaspor la resolución de los problemas habituales que afectaban a innumerables procesos ordinarios civiles y criminales conocidos por los jueces de primera instancia o por los tribunales territoriales ${ }^{63}$.

Asunto diferente son los (reiterados) conflictos de competencia con las autoridades administrativas, en los que es habitual que desde el Gobierno se conmine a la Audiencia correspondiente para que amoneste a los jueces que han actuado contra aquellas ${ }^{64}$. Este "interés", mejor, esta intervención del ejecutivo

62 Es fácil comprobarlo siguiendo, por ejemplo, los resúmenes de méritos y servicios que se publicaron en la Gaceta de Madrid -cuya documentación por extenso se conserva en el Archivo Histórico Nacional-, observando las fechas de las cesantías o suspensiones de los jueces y estableciendo su reflejo en los cambios politicos que se produjeron. Para más detalles Pedro Ortego, Inamovilidad, interinidad e inestabilidad, op. cit., passim.

63 Podemos hallar algunas de las causas en la intervención del diputado y magistrado de la Audiencia de Sevilla Pablo Santafé, en la sesión del 18 de abril de 1822, rechazando la visita general a las causas criminales en las Audiencias territoriales, medida que llega a calificar de "degradante a los tribunales" (Diarios de las sesiones de Cortes. Legislatura de 1822, J.A. Garcia, Madrid, 1872, tomo II, $n^{\circ} 59$, p. 898). En el fondo, lo que se debate es que un estricto control sobre la actividad judicial y la imposición de sanciones a los juzgadores podría llegar a poner en duda el prestigio de la administración de justicia, pero, al mismo tiempo, era necesaria su realización para demostrar que se estaba supervisando su correcto desempeño, aunque en último término se buscaran diferentes soluciones para evitar hacer efectivas las condenas a cualquier juez. Los pocos datos que conocemos sobre jueces y magistrados encausados y condenados en firme a lo largo del siglo XIX fundamentarian esta afirmación.

64 La Gaceta de Madrid está repleta de conflictos de competencias entre jueces de primera instancia y autoridades municipales y provinciales, singularmente gobernadores civiles. Pero lo que no reflejan sus páginas es la conminación a los jueces dirigida por el ministro de Gracia y Justicia al comunicar la resolución de aquellos. Es preciso acudir a la documentación de archivo. Entre otras muchas: "Ministerio de Gracia y Justicia. Negociado 5․ Por la Presidencia del Poder Ejecutivo se ha comunicado a este Ministerio con fecha treinta y uno de mayo último lo que sigue. La Sección de Estado y Gracia y Justicia del Consejo de Estado al evacuar informe en el expediente en que el gobernador de la provincia de Zaragoza denegó al juez de primera instancia del distrito del Pilar de Zaragoza la autorización para procesar a don Enrique de Solano, alcalde de Alfajarín, acusado de delito de denegación de auxilio a los particulares ha propuesto la siguiente. Acordada. Asimismo, ha acordado la Sección llamar la atención de V.E. hacia las omisiones en que ha incurrido don José 
sobre el judicial es más fácilmente apreciable en cuanto al enjuiciamiento de los asuntos contencioso-administrativos, con particular atención a las autorizaciones administrativas previas para enjuiciar a funcionarios o autoridades 65 . Por ello, cuando definitivamente se establece la jurisdicción contencioso-administrativa en España ${ }^{66}$, y ya estamos hablando de finales del siglo XIX y comienzos del siglo XX, pudo recuperarse algo de independencia por parte de ese medio poder, o de esa teórica armonía entre poderes ${ }^{67}$.

En virtud de cualquiera de los trámites normativos, los Gobiernos consiguieron controlar, con mayor o menor intensidad, al llamado "poder judicial". De esta manera podriamos afirmar, sin temor a equivocarnos, que en realidad nos encontramos con un poder y medio de los tres que hablaba

Antonio de la Campa, juez de primera instancia del distrito del Pilar de Zaragoza en la tramitación de este expediente, pues ni consultó al promotor fiscal antes de solicitar la competente autorización ni ha fundado el auto en que se mandó pedirla. Es pues evidente que con estas omisiones el expresado juez ha infringido el artículo 30 del Reglamento para la ejecución de la Ley de 25 de septiembre de 1863 vigente en la materia y las circulares de 23 de diciembre de 1858, 7 de febrero de 1861 y 18 de octubre de 1864. En cuya atención la Sección entiende que si V.E. lo estimare justo deberian hacerse al mencionado juez las prevenciones correspondientes por el conducto debido a fin de que en lo sucesivo cumpla exactamente lo mandado en las disposiciones que quedan citadas... Madrid, cuatro de junio de mil ochocientos sesenta y nueve. El subsecretario. Trinidad Sicilia" (Archivo Histórico Provincial de Zaragoza, J/4193/2, f. 69). Sobre estos conflictos, Blanca Lozano Cutanda, "Los conflictos entre la administración y los tribunales: perspectiva histórica y nueva configuración", Revista de Administración Pública, no 118, 1989, pp. 175-220.

65 Trámite que llegó a constitucionalizarse. Constitución de 1876: "Art. 77. Una ley especial determinará los casos en que haya de exigirse autorización previa para procesar, ante los Tribunales ordinarios, a las autoridades y sus agentes". Por el contrario, la Constitución de 1869 había omitido este requisito: "Art. 30. No será necesaria la previa autorización para procesar ante los Tribunales ordinarios a los funcionarios públicos cualquiera que sea el delito que cometieren". Para el periodo anterior, Juan Manuel Olarieta Alberdi, "La autorización administrativa previa para procesar a funcionarios públicos (Administración Pública y tribunales a mediados del siglo XIX)", Revista de Estudios de la Administración Local y Autonómica, no 246, 1990, pp. 227-279. Sara Moreno Tejada, "El enjuiciamiento de los empleados públicos: la autorización administrativa previa (1845-1868)", Ius Fugit, n 21, 2018, pp. 277-297. Una visión más amplia, Marta María Lorente Sariñena, "De la transcendencia constitucional de un mecanismo institucional: la autorización para procesar a los funcionarios públicos”, en Derecho, Historia y Universidades. Estudios dedicados a Mariano Peset, Universitat, Valencia, 2007, tomo II, pp. 117-127; y, "División de poderes y contenciosos de la administración: una -breve- historia comparada", en Carlos Garriga (coord.), Historia y Constitución: trayectos del constitucionalismo hispánico, Centro de Investigación y Docencia Económicas, México, 2010, pp. 307-345.

${ }^{66}$ Ley para el ejercicio de la jurisdicción contencioso-administrativa de 13 de septiembre de 1888, conocida como de Santamaría de Paredes, cuyo texto definitivo se alcanza por Real decreto de 22 de junio de 1894. Véase, entre otros muchos trabajos, Marta Lorente Sariñena (dira.), La jurisdicción contencioso-administrativa en España. Una historia de sus orígenes, CGPJ, Madrid, 2009, [Cuadernos de Derecho Judicial, nº VII, 2008]. Juan Ramón Fernández Torres, Historia legal de la jurisdicción contencioso-administrativa (1845-1998), Iustel, Madrid, 2007.

${ }^{67}$ Aunque no faltó quien reclamara, asimismo, la independencia del poder administrativo frente al judicial. En este sentido, véase el debate de la sesión del Congreso de los Diputados de 11 de febrero de 1885, en la que, por ejemplo, Canalejas tras mantener que todas las Constituciones españolas "llaman poder judicial a la administración de justicia", aclara que la de 1876 "no dice nunca al referirse al parlamento, al referirse al rey, poder legislativo, ni poder real; por donde no puede establecerse la diferencia de los titulos como una nota característica de los poderes" (Diarios de sesiones de Cortes. Congreso de los Diputados. Legislatura 1884-1885, Hijos de J.A. García, Madrid, 1885, tomo V, nº 87, pp. 2186-2195). 
Montesquieu: el ejecutivo que extiende su control y anula al legislativo; y medio poder judicial, del que interesa a los gabinetes ministeriales, sobremanera, el control sobre toda la jerarquía judicial, desde los magistrados del Tribunal Supremo a los jueces de primera instancia de entrada, porque la otra mitad, la que se refiere a la administración de justicia a los particulares en asuntos civiles y criminales mediante la aplicación de la ley, no tiene apenas interés para los políticos en general, además de suponer una infracción, de verificarse, al texto constitucional y, desde 1870, al legal.

A lo expuesto conviene agregar otra circunstancia que remonta su propuesta a Montesquieu, aunque algo se acaba de apuntar: los poderes legislativo y ejecutivo atienden a asuntos de transcendencia general, que afectan al conjunto de la ciudadanía. Por el contrario, los jueces y tribunales el pretendido poder judicial- limita su actividad a los asuntos particulares entre ciudadanos. De otro modo, a los órganos ejecutivos y legislativos les correspondian las leyes politicas, mientras que a los órganos judiciales solo les incumbian las leyes civiles, en los términos expresados por Montesquieu. De este modo, el Rey con las Cortes, o solo éstas, y el Rey -con sus ministros- gozan de atribuciones que interesan a toda la nación, mientras que los tribunales y los jueces solo atenderian a los particulares individualmente considerados. En consecuencia, desde planteamientos politicos, el pretendido poder judicial no podría alcanzar la altura o equipararse a los otros dos, pues su ámbito de actuación no pasaba de los intereses individuales en lo civil o en lo criminal. Legislativo y ejecutivo tienen cabezas definidas, el judicial carece de tal concreción, pues no se determinan con exactitud qué o cuáles son esos tribunales que ejercen tal poder, pues de aceptarse que recae en todos equiparariamos al Tribunal Supremo con las Audiencias territoriales, lo cual no entraría, en buena lógica, en la configuración de un poder.

En suma, más que de "poder judicial" -del que hablaban los textos progresistas- quizá, como en el medio ambiente, podríamos hablar del "medio poder judicial", o mejor de "orden judicial" o de "administración de justicia", como plasmaron algunos textos constitucionales españoles moderados ${ }^{68}$. Es decir, no puede entenderse realmente como un poder independiente en cuanto a su configuración orgánica, pero sí en cuanto al ejercicio de sus atribuciones en la aplicación de la ley en los procesos civiles y criminales. Cuando no había partidos politicos, pudo haber un poder judicial (al menos en la rúbrica constitucional) con un Supremo Tribunal de Justicia hasta cierto punto independiente ${ }^{69}$; pero a medida que los partidos políticos se fueron configurando, asentando y haciéndose

68 Se ha calificado, desde planteamientos diferentes a los aquí reflejados, de "disminuido poder judicial", en cuanto "instrumento de la garantía de lo previsto por el legislativo", por Javier Sánchez Rubio, "Del gobierno de los jueces al poder judicial. El tránsito del modelo jurisprudencial del ius commune al poder judicial del constitucionalismo", Boletín de la Facultad de Derecho, $n^{\circ}$ 18, 2001, pp. 51-79.

69 En la Constitución de 1812, "se llegó a una solución intermedia entre la pergeñada en los trabajos preconstitucionales y la diseñada por la comisión de Constitución: un tribunal que era al tiempo centro de autoridad y tribunal de responsabilidad de los magistrados y empleados", según Fernando Martínez Pérez, Entre confianza y responsabilidad. La justicia del primer constitucionalismo español (1810-1823), CEPC, Madrid, 1999, p. 324; y del mismo, "Constitución de la Justicia en Cádiz. Jurisdicción y Consultas en el proceso constituyente de la potestad judicial”, Anuario de Historia del Derecho, nº 81, 2011, pp. 377-407. 
fuertes, se aprecia mejor la influencia del ejecutivo sobre los integrantes del poder/orden judicial. Puede admitirse la afirmación, aunque sea la muestra de otras similares, de Silvestre Pinheiro Ferreira de que no siendo independiente un magistrado, nunca lo sería -quizá, matizo, del todo- el poder judicial ${ }^{70}$. Puede admitirse la separación funcional, pero siempre y cuando se acepte que uno se inmiscuye constantemente en los otros dos, directa o indirectamente; por lo cual nunca sería equilibrada ni, mucho menos, rígida; y siempre existiria una interdependencia (camuflada, si se quiere) en la que se advierte una subalternización. No se trata sólo de descubrir el abusivo ejercicio de competencias entre poderes, sino de estudiar con detenimiento los mecanismos de intervención del ejecutivo en el judicial y de encontrar las razones últimas de tal interés, en las que el legislativo parece un invitado pasivo. Lo cual permitiría, a mi juicio, diferenciar dos expresiones que, aunque discutibles, permiten apreciar la realidad más allá de los textos: poder de juzgar (potestad para juzgar) y poder judicial (estructura orgánica) ${ }^{71}$. Lo funcional y lo orgánico con dos centros diferenciados: el primero, cuyo vértice se situará normativamente en el Tribunal Supremo mediante la casación; y el segundo, situado en el Ministerio de Gracia y Justicia, de quien depende el acceso y la jerarquia ${ }^{72}$. Es decir, que el pretendido poder judicial no tenía como cabeza en lo orgánico un órgano jurisdiccional, sino un miembro del poder ejecutivo ${ }^{73}$. En una y otra faceta encontramos argumentos constitucionales, legales y reglamentarios para fundamentar dicha dualidad: porque constitucional era que los tribunales administraran justicia en lo civil y en lo criminal, como también que al ejecutivo le correspondia el nombramiento de los funcionarios y la vigilancia para que la administración de justicia fuera pronta y cumplida; era legal por cuanto las leyes encomendaron a los tribunales aquella potestad juzgadora, regularon los procedimientos o determinaron las instancias, con independencia de que los principales asuntos relativos al estatuto de los jueces dependieran en último término del Ministerio de Gracia y Justicia;

\footnotetext{
70 Isabel Graes, O poder e a justiça em Portugal no século XIX, op. cit., p. XIV.

71 Jean-Pierre Royer ha planteado que si el poder judicial no podía ser ejercido por el cuerpo legislativo ni por el rey, "cela suffira-t-il pour pouvoir parler d'un véritable pouvoir judiciaire? Sûrement pas, mais plutôt d'une simple "fonction", distincte des deux autres, la législative el l'exécutive, et subordonnée" (Histoire de la justice en France, PUF, París, 1996, p. 265).
}

72 Por su parte, Enrique Álvarez Cora manifiesta que, a diferencia del juez del absolutismo, "el juez del Estado liberal no es un juez subrogado, y su nombramiento, aun en manos ejecutivas, no entraña una sustitución, y por eso posibilita la argumentación de un poder distinto. Esto es lo que quiere decir que el juez liberal aplique las leyes: no las crea de forma subrogada y su deber es acomodarlas en las circunstancias de la práctica jurídica" (La arquitectura de la justicia burguesa, op. cit, p. 37, nota 62).

${ }^{73}$ Sin duda el diputado portugués Alfonso Freire lo expresó con meridiana claridad: "Eu não sei que haja senão dois poderes, legislar, e executar. Isto de poder judicial, a meu ver, foi uma espécie de vangloria; os juízes devem ser independentes, depois que são nomeados" (Diario das Cortes Geraes e Extraordinarias da Nação Portugueza, Impressão Nacional, Lisboa, 1821, tomo III, $\mathrm{n}^{\circ}$ 156, p. 1949, sesión de 20 de agosto de 1821). En España se planteó en términos similares: "Mas aunque el poder judicial sea una emanación del poder real o ejecutivo, es, sin embargo, independiente de él en el ejercicio de sus funciones. Ni el poder ejecutivo ni el legislativo deben influir directa ni indirectamente en los fallos de la justicia”, en palabras de Joaquín Escriche, Diccionario razonado de legislación y jurisprudencia, Eduardo Costa, Madrid, 1875, voz juez, p. 432. Esta falta de corporeidad ajusta bien con la identificación que hace Bartolomé Clavero del espiritu judicial (El orden de los poderes, op. cit., p. 266). 
y, por último, porque durante décadas aspectos sustanciales del procedimiento fueron regulados por via de decreto y, por disposiciones de este rango se regularon el acceso, la promoción o los traslados de jueces y magistrados como también su responsabilidad.

La independencia se postula, como vemos, en cuanto al ejercicio de la potestad ${ }^{74}$, pero no se reclama su extensión para los nombramientos, al menos hasta la implantación, constitucional y legal, de la oposición como procedimiento de acceso a la Judicatura. Pero, incluso después, la circunstancia de que corresponda al ministro de Gracia y Justicia la convocatoria de tales ejercicios mediatiza tal independencia, más aún si atendemos a la utilización del llamado cuarto turno.

Es en la parte funcional donde hay que situar al medio poder, porque en el ejercicio de la administración de justicia en los pleitos civiles y en las causas criminales es donde se ejercitan sus atribuciones exclusivas ${ }^{75}$, y donde a través de la nulidad/casación civil (1838) y más tarde de la casación en asuntos criminales (1870) se logra unificar la jurisprudencia. En este ámbito de actuación, la intervención de los políticos, ministros o parlamentarios, es proporcionalmente reducida y, en la mayoria de las ocasiones, dificil de probarse, por lo que el conjunto de jueces y magistrados aparecen como juzgadores independientes. En otras palabras, de acuerdo con las concepciones decimonónicas, la independencia es preciso vincularla a la potestad de juzgar y no necesariamente a la configuración orgánica de un poder.

Pienso que deberíamos hablar más de la independencia del juez y menos de la independencia del poder/orden judicial. Más que negar la independencia del

\footnotetext{
${ }^{74}$ Para Cristino Martos, ministro de Estado, "el Poder judicial es un poder muy alto, es un poder independiente, es un poder que puede y debe obrar libremente, con absoluta independencia, en la esfera privativa de sus atribuciones propias; pero es por esto mismo un poder responsable, porque la responsabilidad es el principio que corresponde al principio de la libertad" (Diarios de sesiones de Cortes. Congreso de los Diputados. Legislatura 1872-1873, J.A. García, Madrid, 1873, tomo III, $\mathrm{n}^{\circ}$ 80, sesión de 16 de diciembre de 1872, p. 2395). Puede plantearse qué entendia por "esfera privativa de sus atribuciones propias", porque a mi juicio se limitaba a la de aplicar las leyes en las causas civiles y criminales, pero omite implícitamente otras funciones atribuidas a los jueces, como la que tenían en los procedimientos electorales, bien al amparo de la ley, bien por interés gubernativo.

75 Así el art. 63 de la Constitución de 1837 y el art. 66 de la Constitución de 1845: "A los tribunales y juzgados pertenece exclusivamente la potestad de aplicar las leyes en los juicios civiles y criminales; sin que puedan ejercer otras funciones, que las de juzgar y hacer que se ejecute lo juzgado". El art. 91 de la Constitución de 1869 simplificó la redacción: "A los Tribunales corresponde exclusivamente la potestad de aplicar las leyes en los juicios civiles y criminales". Incluso fue más allá al determinar su art. 92 que "los Tribunales no aplicarán los reglamentos generales, provinciales y locales sino en cuanto estén conformes a las leyes". Cabe recordar, asimismo, las rúbricas de tres títulos de la Constitución portuguesa de 1822: Do Poder Legislativo ou das Cortes, Do Poder Executivo ou do Rei, y Do Poder Judicial. Este último no se identifica con ninguna institución concreta, como se hace con los otros dos. Una inconcreción que podría salvarse, sino fuera por su indeterminación, en dos artículos concretos: art. 30, según el cual, "estes poderes são legislativo, executivo e judicial. O primeiro reside nas Cortes com dependência da sanção do rei (artigos 110, 111 e 112). O segundo está no rei e nos secretários de Estado, que o exercitam debaixo da autoridade do mesmo rei. O terceiro está nos juízes. Cada um destes poderes é de tal maneira independente, que um não poderá arrogar a si as atribuições do outro"; y en el art. 176, de acuerdo con el cual "o Poder judicial pertence exclusivamente aos juízes".
} 
poder judicial si un juez no la tiene, creo que debiera plantearse desde la primera perspectiva, es decir, de la del juez individualmente considerado, desde la del juez que tiene que resolver un caso concreto y que se aisla y resiste cualquier injerencia, en especial la política más cercana, la caciquil. Es decir, cumple de forma independiente la misión constitucional de juzgar. Esto es lo que más aprecia el ciudadano de a pie, porque es lo que más le afecta e interesa. Es la honestidade pessoal de la que habla el Decreto portugués de 29 de julio de 188676. De ahí, las reiteradas alusiones para que los juzgadores no se entremezclaran en los negocios politicos ${ }^{77}$.

Al margen de lo expresado en el párrafo anterior, es manifiesta la divergencia entre los procedimientos ministeriales, es decir, la práctica política, y los principios constitucionales, singularmente el de inamovilidad. La autoridad (política) de las palabras y de los textos (constitucionales y legales) en los que están insertos los principios fundamentales es transcendental en la teoria, aunque la realidad fuera por camino opuesto, o al menos muy distante. Especialmente a través de la designación y la promoción, por un lado, y la defenestración, por otro, se impuso un control ideológico sobre magistrados y jueces inferiores. La meritocracia politica, conseguida por los servicios prestados al partido gobernante, aunque de duración temporal, muestra la recompensa servicial. Estas circunstancias no implican que, al resolver sobre la propiedad de unas tierras, la resolución de un contrato o la querella por un robo, la impronta politica se trasladara miméticamente al procedimiento judicial $\mathrm{y}$, en último término, al fallo ${ }^{78}$.

A pesar de la regulación del ámbito orgánico por ley, continuaron los subterfugios para soslayar su cumplimiento por parte del gabinete de turno. Después de haberse proclamado constitucionalmente la inamovilidad judicial en la Constitución de 1869 y desarrollado en la Ley de 1870, desde la prensa se denunciaba en 1872 que "en los dos años últimos ha habido tantos movimientos generales del personal de los tribunales como elecciones de diputados y senadores, $\mathrm{y}$ ha habido juez que en un mes ha sido trasladado cuatro veces, $\mathrm{y}$ juzgado que ha conocido cerca de una docena de jueces y promotores"79. Esta crítica, que se reproducía tras cada cambio ministerial en Gracia y Justicia, tuvo mayor protagonismo que las deficiencias en la administración diaria de la justicia.

76 Véase Isabel Graes, O poder e a justiça em Portugal no século XIX, op. cit., p. 63.

77 Así se reafirmó en numerosas ocasiones, tantas como se incumplió. El fiscal del Tribunal Supremo Huet lo puso de manifiesto, al señalar que, sin la incompatibilidad de funciones judiciales con todo cargo político y administrativo, "no alcanzarán nunca los que la ejerzan toda la independencia y el respeto que han menester para desempeñar cumplidamente sus deberes" ("Dictamen escrito y propuesto por D. José Maria Huet, sobre el Proyecto de ley de bases para la organización de los tribunales del fuero común", Revista General de Legislación y Jurisprudencia, $\mathrm{n}^{\circ} \mathrm{XXV}, 1864$, pp. 5-29, la cita en p. 8).

78 Son habituales las menciones coetáneas a cómo los malos abogados eran los que pasaban a integrarse en la estructura judicial con el fin de asegurarse un sustento y una posición social. Los abogados curtidos ganaban más dinero ejerciendo la abogacía, por lo que rechazaban incorporarse a la Judicatura. Esta circunstancia era más evidente con motivo de los bruscos cambios políticos. Vid. Pedro Ortego, Inamovilidad, interinidad e inestabilidad, op. cit., pp. 169174.

${ }^{79}$ La Época de 4 de julio de 1872. 
Puede servirnos de guía lo sucedido con el mecanismo objetivo de acceso a la Judicatura. En España, como en Portugal, durante la segunda mitad del siglo XIX se vivió un debate entre el concurso, para elegir (a dedo) al más adecuado a la plaza por sus méritos (políticos) y circunstancias; y la oposición o examen, para que triunfara quien más conocimientos demostrara $y$, por extensión, que el ingreso marcara el criterio a seguir para la promoción interna en la Judicatura y la Magistratura. En el primer caso, la influencia de quien designa es incontrastablemente mayor que en el segundo supuesto. La preferencia por una u otra opción dependió de la partitocracia. En todo caso, la convocatoria de las oposiciones, la existencia del cuarto turno o los criterios de ascenso, dejaron un amplio margen al poder ejecutivo ${ }^{80}$. En este sentido, durante el turno de partidos en la Restauración se convocaron oposiciones o se acudia al cuarto turno dependiendo del interés del Gobierno, y todo sin perjuicio de lo dispuesto en la Ley de $1870^{81}$.

Si las Cortes y los ministros de Gracia y Justicia no se preocuparon en demasia por el correcto funcionamiento de la administración de justicia impartida diariamente a los ciudadanos, ¿quién se ocupó de ello? La respuesta, en principio, es simple: en primer término, los tribunales territoriales; y, en segundo, la prensa política. Respecto del primero, se trató, en mi opinión, de un control postergado por el de indole politica, ya que, como vengo insistiendo, fue más intenso el control gubernativo sobre la designación, promoción, traslado o cesantia de los jueces, que su actividad al frente de los juzgados y el verdadero control sobre la recta y pronta administración de justicia en los procesos civiles y penales ${ }^{82}$. De eso ya se encargaban las Audiencias territoriales, o más en

80 El diputado Alfonso González recriminó a Francisco Silvela su actitud cuando fue ministro de Gracia y Justicia, porque su misma lógica se podia aplicar a los jueces ascendidos cuando ejerció tal cargo, llegando a mencionar un caso de traslado o sustitución por motivaciones politicas, alegando que, antes de nombrar a ninguno de los aspirantes aprobados en 1884, "nombró juez, por el cuarto turno, a un reprobado de esas oposiciones" (Diarios de sesiones de Cortes. Congreso de los Diputados. Legislatura 1887-1888, Hijos de J.A. Garcia, Madrid, 1888, tomo II, $\mathrm{n}^{\circ} 31$, sesión de 21 de enero de 1888, pp. 763-769).

81 En un intenso debate entre el ministro de Gracia y Justicia, Alonso Martínez, y la oposición conservadora, habido en la sesión de 27 de marzo de 1882, en punto a la independencia judicial, llegó a manifestar lo siguiente: "Cada uno de vosotros es un cacique en su distrito, que tenéis en el bolsillo al juez de primera instancia, que hace lo que vosotros queréis. ¿Queréis que encause a los ayuntamientos? Pues los aprisiona y los tiene encausados hasta que vosotros queráis. ¿No es verdad que la noticia es nueva? Porque esos jueces tan malos, esos magistrados tan malos, esos tribunales tan malos que se supeditan ante el Poder ejecutivo y ante la voluntad de los ministros, son vuestros jueces, son vuestros magistrados, son vuestros tribunales; y si el Poder judicial está en nuestro país tan rebajado, es el Poder judicial que nos habéis entregado vosotros". Mientras que Cánovas sostuvo lo contrario al afirmar que "la verdad es que no hay ejemplo de que en ningún país, ni bajo ninguna Constitución, el Poder judicial sea un verdadero poder" (Diarios de sesiones de Cortes. Congreso de los Diputados. Legislatura 1881-1882, Viuda e hijos de J.A. García, Madrid, 1882, tomo VI, nº 90, pp. 2386 y 2368, respectivamente). Lo cierto es que, por los datos recabados para los juzgados aragoneses, Alonso Martínez se comportó con relación a los jueces de primera instancia en los mismos términos que Francisco Silvela.

82 Caben opiniones divergentes -quizá no tanto- de acuerdo con la documentación manejada. En este sentido, a la vista de los expedientes personales de jueces y magistrados estudiados, Alicia Duñaiturria Laguarda concluye afirmando que, de los procedimientos empleados por las Salas de gobierno de los tribunales, predominó "especialmente el control procesal seguido del politico" 
concreto, las salas de justicia y los órganos de gobierno de aquellas, creados y en ocasiones vigilados desde las instancias ministeriales a través de los fiscales ${ }^{83}$.

Además, frente a cierta atonía en la intervención de diputados y senadores, se alzaba la llamada "opinión pública", que no era otra cosa que las opiniones de los diarios opuestos al Gobierno, estuvieran vinculados ideológicamente o no a la minoría parlamentaria, que formaban una pretendida opinión crítica que desaparecia tan pronto como los allegados ideológicos tomaban el control del ejecutivo, lo que permitía, a los otrora periódicos gubernamentales configurar una nueva opinión pública ${ }^{84}$. Así pues, la opinión pública tenía siempre un rasgo común: la oposición al poder político dominante.

En la prensa politica no es complicado hallar alusiones a la mala administración de justicia o a la dejación de las Cortes o del Ministerio de Gracia y Justicia para atajar normativamente estos problemas, partiendo de que cada periódico tiene vínculos con determinada formación política. No obstante, de ordinario es más fácil encontrar en la prensa menciones a determinados procesos, sobre todo a partir de la Restauración, habitualmente causas criminales de gran repercusión social, de las que tan solo hallamos aspectos secundarios, o menciones a procesos civiles y/o penales derivados del caciquismo ${ }^{85}$, tangenciales a los procedimientos electorales o con otras connotaciones politicas ${ }^{86}$.

(“¿Cómo se controló a los jueces en el siglo XIX? Cuatro formas de reproches a la luz de los expedientes personales", op. cit., p. 397).

83 Recuérdese las Juntas gubernativas de los Tribunales creadas por Real Decreto de 5 de enero de 1844, calificado de "adicional al Reglamento del Tribunal Supremo de Justicia y a las Ordenanzas de las Audiencias", y completado con la Real Orden de 9 del mismo mes y año. Estas Juntas gubernativas de las Audiencias fueron suprimidas por Real Decreto de 9 de septiembre de 1854 y restablecidas por otro de 28 de noviembre de 1856. Sin olvidar las Salas de gobierno reguladas en la LOPPJ de 1870. Para mayor concreción, Julia Solla, La discreta práctica de la disciplina, op. cit., pp. 359-379. Con el fin de conocer su actuación, la remisión debe hacerse a $\mathrm{M}^{\mathrm{a}}$. Teresa Bouzada, La responsabilidad disciplinaria de los jueces en Galicia según los asientos de los Libros de Registro de la Audiencia de La Coruña: 1868-1900", op. cit., passim.

${ }^{84}$ Abundantes ejemplos de estos cambios en la prensa politica pueden verse en Pedro Ortego, Inamovilidad, interinidad e inestabilidad, op. cit., passim.

85 Reproduzco un ejemplo clarificador: "Aún recordamos la conferencia que sobre prácticas administrativas etcétera explicó hace pocos años en el Ateneo de Madrid: decía que los Gobiernos ponen los jueces a disposición de los diputados ministeriales, y que aquellos (los jueces) al dictar las sentencias atienden más a las indicaciones de los caciques que a las leyes. Esta afirmación del Sr. Silvela profesor del Ateneo envuelve una terrible censura al Sr. Silvela ministro de Gracia y Justicia", La República de 25 de febrero de 1885. Las cursivas en el texto. Reproducido en Pedro Ortego, Inamovilidad, interinidad e inestabilidad, p. 396, nota 180. En realidad, se trató de una conferencia pronunciada por Luis Silvela y las palabras que pronunció fueron: "en la tramitación y en la sentencia de las causas criminales y en los negocios civiles atienden más a las indicaciones de los caciques que sirven al diputado que a las leyes civiles y criminales" (Telesforo Ojea Somoza, "El parlamentarismo", Revista de Legislación y Jurisprudencia, $\mathrm{n}^{\circ}$ 64, 1884, pp. 515-560, la cita en 548).

86 Entre otros trabajos de referencia, Carlos Petit Calvo, "La célebre causa del crimen de Fuencarral. Proceso penal y opinión pública bajo la Restauración", Anuario de Historia del Derecho Español, $\mathrm{n}^{\circ}$ 75, 2005, pp. 369-412. Alicia Duñaiturria Laguarda, "Se abrió la veda al morbo judicial: el crimen de la calle Fuencarral a través del diario La República", en Cristina Carretero González (dira.), El Derecho en los medios de comunicación, Aranzadi, Madrid, 2013, pp. 43-68. 
No puede apartarse de esta visión que "la sociedad se mostraba indiferente a la falta de una ley sobre tribunales, pues andaba más preocupada por el devenir diario de los jueces y sus actuaciones" 87 . Esta situación era tal que, si bien los traslados de jueces eran habitualmente considerados como una manifestación del nepotismo ministerial, en ocasiones eran recibidos con satisfacción. Si descendemos a lo particular, a las situaciones en que los ciudadanos tenian que acudir a la vía judicial, lo que existe es preocupación, con independencia de la difusión simplista de tópicos. En este sentido, Emilio Bravo afirmaba en 1864:

"Es muy frecuente, y en algunos hasta una mania, el hablar de abusos de la Administración de justicia, de ineficacia en la acción de los Tribunales y de insuficiencia en las disposiciones legales; $y$ sin embargo, si se desciende a profundizar las circunstancias de cada caso, se verá que ni hubo tales abusos, ni los jueces dejaron de cumplir con su deber, ni las leyes fueron insuficientes; sino que, o los testigos faltaron a la verdad, o se neutralizó la acción de la justicia por la confabulación, o los mismos interesados quejosos dieron ocasión al mal con algún acto suyo. Esto, prescindiendo de los litigantes que, llenos de ira o de intemperancia, promueven en todas partes la conversación de sus pleitos, inventando incidentes, exagerando circunstancias, y presumiendo siempre que el juez está a favor de su contrario. Este vicio se ha extendido tanto, que ha habido algunos que han apelado a la prensa. Lamentándose de las providencias judiciales que no le acomodaban; $y$ aún recordamos la extravagancia de un senador, que, habiendo perdido un pleito, interpeló sobre ello en el Senado al ministro de Gracia y Justicia"88.

Lo que, sin duda, más preocupó a los Gobiernos fueron las atribuciones no procesales de los jueces y tribunales, en especial de los primeros. La participación de estos jueces en los procesos electorales ${ }^{89}$, y en particular el control ideológico de la población más cercana, que era la de las cabezas de

87 Pedro Ortego, Inamovilidad, interinidad e inestabilidad, op. cit., p. 118.

88 De la administración de justicia, op. cit., p. 473. Se refiere a lo sucedido en la sesión de la Cámara Alta el 21 de febrero de 1861 con motivo de la interpelación de Eusebio de Calonge Fenollet "sobre el modo cómo se guardan por los funcionarios del orden judicial las inmunidades constitucionales de los señores senadores y diputados", durante la cual Fernández Negrete argumentó que "los tribunales de justicia son un poder o institución independiente de los demás poderes del Estado", pero a los efectos de su función, porque "el ministro no puede defenderlos, toda vez que no conoce ni tiene obligación de conocer todas las causas y pleitos que deciden los tribunales, porque estos fallan independientemente del ministro" (Diarios de sesiones de Cortes. Senado. Legislatura 1860-1861, Imprenta Nacional, Madrid, 1861, tomo II, nº 78, pp. 839-857).

89 Por citar un ejemplo, la Ley de 18 de julio de 1865 atribuía a los jueces la resolución de las demandas para ser incluidos en las listas electorales: "Art. 21. Al tiempo de promulgarse esta ley se adicionarán las listas electorales vigentes con arreglo a las disposiciones transitorias comprendidas en el título X, y así adicionadas estas listas constituirán el censo electoral permanente. Art. 22. Ultimada esta reforma, y publicadas las listas que de ellas resulten, el derecho electoral y la consiguiente inscripción en el censo solamente podrán obtenerse y perderse por virtud de declaración judicial, hecha a instancia de parte legitima por los trámites establecidos en esta ley. Art. 23. Para hacer esta declaración son competentes, con exclusión de todo fuero, los jueces de primera instancia de la jurisdicción ordinaria de los partidos judiciales comprendidos en el distrito o sección en cuyas listas haya de hacerse la inscripción o la exclusión del elector". Y junto con su participación en la elaboración de las listas, el escrutinio era otra intervención clave: "Art. 86. El juez de primera instancia del partido cabeza de distrito, y dónde hubiere más de uno, el juez decano presidirá con voto la Junta de escrutinio general" (Gaceta de Madrid de 31 de julio). 
partido judicial, antes de verificarse las elecciones generales y/o municipales ${ }^{90}$, se consideró un aspecto crucial, primero en la consolidación de una monarquía liberal y, más tarde, para conseguir mayorias en las Cortes. Por este motivo, las depuraciones ideológicas de jueces y magistrados no cabe reducirlas a las etapas de gobiernos absolutistas ${ }^{91}$, porque en España se fueron sucediendo a lo largo del siglo XIX, incluso agravadas en etapas progresistas ${ }^{92}$. La realidad muestra que los traslados de jueces antes de los procesos electorales no fueron tan intensos como los que se produjeron después de celebradas las votaciones o el habitual levantamiento y con un nuevo Gobierno ${ }^{93}$.

La realidad era desalentadora. Como se ha resaltado, el control ejercido desde el Ministerio de Gracia y Justicia, con independencia de quién fuera su titular, estaba más interesado en las actividades extraprocesales de los jueces, en particular las que giraban alrededor de las elecciones, que sobre aquellas que incidian estrictamente en la administración de justicia. La inmediata consecuencia de dicho interés es la notable desatención sobre la actividad y funcionamiento de los juzgados inferiores, en los cuales se observan importantes desajustes derivados de la amovilidad por la que tuvieron que pasar los jueces de primera instancia. A lo cual es preciso agregar los problemas centrados en la tramitación y resolución por dichos juzgadores de los asuntos que les llegaban, de donde surgieron criticas, antes y después de 1870, acerca de las deficiencias de su formación que, por razones obvias, se trasladaron a la administración de

90 Sirva de muestra, la Real Orden de 12 de marzo de 1851: "El Gobierno de S. M. cumpliendo una de sus primeras obligaciones, se propone evitar eficazmente que las personas consagradas al severo deber de administrar justicia tomen parte activa en las cuestiones electorales a riesgo de perder el prestigio y la imparcialidad absolutamente imprescindibles para el recto y buen desempeño de su honroso cargo... El ministro que suscribe se promete de las nobles y honrosas cualidades que han adornado siempre a la magistratura española que no serán necesarios grandes esfuerzos por su parte para conseguir que el propósito del Gobierno de S. M. se realice plenamente; pero esta fundada esperanza será un motivo más, cuando la falta ocurra, para que su represión sea tan grave como el decoro de la misma magistratura aconseja, y tan pronta como lo exige la naturaleza de los deberes confiados a los individuos del orden judicial, porque comprendiendo aquellos la decisión de los derechos y de los intereses públicos y privados de mayor importancia, no solo debe evitarse con todo esmero la falta de imparcialidad y la ocasión de incurrir en ella sino hasta la apariencia o la sospecha de una y otra..." (Gaceta de Madrid de 13 de marzo). El hecho de la reiteración de disposiciones similares ratifica, en perspectiva oficial, la ausencia de imparcialidad por parte de los jueces en periodos electorales.

91 Sobre la etapa de Fernando VII, Jean-Philippe Luis, L'utopie réactionnaire: épuration et modernisation de l'État dans l'Espagne de la fin de l'Ancient Régime (1823-1834), Casa de Velázquez, Madrid, 2002. Pedro Ortego Gil, Entre jueces y reos. Las postrimerias del Derecho penal absolutista, Dykinson, Madrid, 2015, pp. 95-115, en particular. Con posterioridad continuaron justificándose estas purgas. Es significativo lo que manifestaba el periódico ultramoderado $E l$ Pensamiento Español el 6 de marzo de 1866 a raíz del movimiento de jueces: "Habrá periódicos que clamen contra estos actos ministeriales; nosotros les consideramos necesarios, si se ha de salvar el país, esto es, si han de ganarse las elecciones".

92 Tras los cambios progresistas en 1840,1854 y 1868 se produjeron tales alteraciones en la Judicatura, con innumerables ingresos y cesantias, que, para conseguir tener unos jueces y magistrados adictos a la causa, se pidió la suspensión de la inamovilidad porque, de no hacerlo, se mantendrian los que procedian de la etapa moderada. En 1843, 1856 y 1875 la reacción fue la contraria. Francia también tendrá las suyas. Benoît Garnot, Histoire des juges en France de l'Ancien Régime à nos jours, Nouveau Monde, Paris, 2014, pp. 148-150.

93 Así lo he puesto de manifiesto en Inamovilidad, interinidad e inestabilidad, op. cit., passim. 
justicia recibida por los ciudadanos, singularmente de los partidos judiciales rurales. El control procedimental ejercido por las Audiencias territoriales a través de las demostraciones fue siempre puntual y habitualmente ineficaz, porque mediante la via de equidad los jueces que eran objeto de aquellas vieron alzadas sus sanciones por los mismos magistrados que las imponian, y porque de ordinario no afectaban a su trayectoria posterior dentro de la Judicatura ${ }^{94}$.

De igual manera, se ha afirmado que las deficiencias de dicha mala administración de justicia se padecieron, en particular y con carácter enfermizo, en las zonas rurales, alli donde se situaban los partidos judiciales calificados y clasificados "de entrada". Romero Girón, que fue ministro del ramo, rechazaba esta idea. Para él, siempre quedaba "el consuelo de saber que los errores de los cuales resultan víctimas, aprovechan a la educación de quienes los cometen, que los tendrán muy en la memoria, cuando, merced al ascenso de clase y grado, se encuentren magistrados de un orden superior"95.

En otro frente, la situación era tan caótica y no resuelta ni por el Gobierno ni por las Cortes a través de los presupuestos, que muchos jueces perdian buena parte de sus salarios en los continuos traslados, de manera que hay referencias que muestran que eran los oficiales de los juzgados o los poderosos de las cabezas de partido quienes, en ocasiones, adelantaban dinero a estos jueces para poder atender a las mínimas necesidades cuando tomaban posesión del juzgado. Un dinero que mediatizaba sus posteriores actuaciones procesales, como se denunció en alguna ocasión ${ }^{96}$.

Podemos apreciar, en suma, que fue el ejecutivo y no el legislativo el que controló en España la regulación de todo cuanto rodeó a la administración de justicia durante la mayor parte del siglo XIX. Cierto es que en las Cortes se aprobaron leyes, pero las que lo fueron, en el ámbito que nos ocupa, vinieron

94 Puede encontrarse información interesante en Pedro Ortego Gil, "Control y descontrol ministerial sobre jueces y juzgados de primera instancia (1834-1902)"; $\mathrm{y}, \mathrm{M}^{\mathrm{a}}$. Teresa Bouzada Gil, "La responsabilidad disciplinaria de los jueces en Galicia según los asientos de los Libros de Registro de la Audiencia de La Coruña: 1868-1900", op. cit. Esta última historiadora del Derecho termina destacando que la Audiencia territorial de La Coruña impuso a los jueces de $1^{\mathrm{a}}$ instancia correcciones que eran propias de los auxiliares a tenor de la Ley orgánica de 1870, aunque a partir de la Ley de enjuiciamiento de 1881 fueron normativizadas también para jueces y tribunales, aunque marcando ciertos márgenes de discrecionalidad, para concluir que "las correcciones disciplinarias impuestas, aparentemente, no supusieron graves consecuencias en las carreras judiciales de los jueces sancionados".

95 Discurso leido por el Excmo. Sr. D. Vicente Romero y Girón, ministro de Gracia y Justicia, en la solemne apertura de los tribunales, celebrada en 15 de setiembre de 1883, Ministerio de Gracia y Justicia, Madrid, 1883, p. 12.

96 El senador Benito Ulloa Rey, magistrado del Tribunal Supremo, afirmó lo siguiente: "en el momento que se sabia en un juzgado la traslación de un juez, la curia del juzgado a donde iba trasladado, se dirigía a la curia del juzgado de donde venía el pobre juez y le preguntaba, en qué condiciones económicas venía, y contestaban los otros: pues hemos tenido que darle para el viaje. Ya sabian, pues, que aquel pobre hombre no llevaba ni siquiera con qué comprar una libra de pan, y como la firma de un juez no se cotiza en la Bolsa, es despreciable, pero sí de gran importancia en una sentencia, pasaba un dia y otro luchando entre la conciencia de su deber y la necesidad de tener que valerse de los que se apresuraban a ofrecerle dinero; porque el juez conoce que si pide dinero a un curial, a un pica-pleitos o a un litigante, pierde en absoluto aquella libertad que debe tener todo juez para dictar los fallos" (Diarios de sesiones de Cortes. Senado. Legislatura de 1887, Madrid, 1887, tomo VI, n. 110, sesión de 7 de junio de 1887, pp. 2333-2334). 
marcadas en su inmensa mayoria por la delegación legislativa. Si a ello sumamos el hecho de que los Gobiernos se atribuyeron, durante décadas, la fijación por decreto de los requisitos para el acceso a la judicatura o la creación y categoría de los juzgados -aunque más tarde pasara este asunto a las leyes de presupuestos$\mathrm{y}$, con carácter general, todo lo que rodeaba al estatuto de los jueces o la regulación de trámites procesales y la primigenia redacción de los textos que se convertirian en las leyes de enjuiciamiento, no cabe duda que el poder ejecutivo mantuvo una potestad, casi omnimoda, sobre la administración de la justicia a través, precisamente, de sus administradores, incluso después de la Ley de 1870 mediante la utilización del decreto ${ }^{97}$, a través del cual se alteró y adecuó su contenido a las circunstancias politicas de cada momento. A los Gobiernos poco les preocupó los problemas generados en la administración judicial impartida a los ciudadanos, sus quejas y carestía, en definitiva, eran problemas de y entre particulares. Sí se interesó, en la medida en que formaba parte de sus atribuciones, por el control de la justicia criminal, pero solo ante los hechos que provocaban temores en la población o en los que la represión del Estado, en muchos casos política, debía imponerse, según la ideología predominante.

\section{LA FALLIDA CONSTRUCCIÓN ORGÁNICA DEL PODER JUDICIAL}

Como recogi al principio, aquellas palabras del viejo profesor de la Academia compostelana pueden aplicarse a las circunstancias en las que se desenvolvió la actividad política decimonónica española en el siglo XIX. Un poder, el ejecutivo, marcó la actividad y los tiempos del legislativo y de lo que, a pesar de algunos textos incluso constitucionales, se dio en llamar orden judicial. Se comprende mejor si, en lugar de hablar de separación de poderes, hablamos de separación de atribuciones (potestades) y de órganos que deben ejercerlas.

Existía pavor, en las bancadas parlamentarias y en los diferentes Gobiernos a que, si el poder judicial se constituyera orgánicamente como tal, quedando entre sus facultades la selección y designación de jueces y magistrados, su control y, en general, todas las restantes atribuciones en este ámbito, surgiera un poder incontrolado, en el sentido de que solo en él y ante él se pudieran resolver sus conflictos, quedando al margen de cualquier otro control del legislativo y/o del ejecutivo. De ahí, el rechazo a ese poder incontrolable. Cuando durante la I República se intenta, dificultades de toda índole abocaron el ensayo al fracaso.

No se creó ningún órgano propio, de gobierno o representativo del poder $u$ orden judicial en su conjunto. Propuestas incompletas no faltaron, como el proyecto presentado en 1842 por José Alonso Ruiz de Conejares, que confería al

97 Por citar un ejemplo, la Real orden circular de 9 de octubre de 1878 dispuso que no se suscitaran competencias a la jurisdicción militar para conocer de los delitos que corresponden a la misma de resistencia, agresión a la fuerza armada e insulto a centinelas, incluida la Guardia civil (Gaceta de Madrid de 10 de octubre). Esta disposición dio lugar a una interpelación de Aureliano Linares Rivas al ministro de Gracia y Justicia, Fernando Calderón Collantes, en el Congreso de los Diputados, originando un debate no solo sobre los conflictos de competencia o la unificación de fueros a tenor de la Ley orgánica del poder judicial, sino que abordó las distintas concepciones politicas acerca del mismo y su independencia, desde un punto de vista más teórico que real (Diario de sesiones de Cortes. Congreso de los Diputados. Legislatura 1878, Viuda e hijos de J.A. Garcia, Madrid, 1879, tomo VI, ns ${ }^{\circ} 138$ y 139, sesiones de 30 de noviembre y 1 de diciembre de 1878, pp. 3805-3819 y 3822-3841). 
Tribunal Supremo las propuestas "para todos los destinos de magistrados y jueces, con las noticias, datos y en la forma que se establece"98. Circunstancias a las que no fueron ajenas, en determinadas épocas, la existencia y atribuciones del Consejo de Estado.

En este embrollo es preciso destacar un artículo publicado en 1844 en el Boletin de la Revista de Jurisprudencia y Legislación, sin firma y bajo el titulo "Sobre la administración de justicia"99. Un texto excepcional por publicarse al inicio de la primera década moderada. Frente a la opinión que sostenía que existía un orden judicial, sus autores manifiestan desde el principio que "el poder judicial es un verdadero poder del Estado", por lo cual "puede y debe existir por sî". Su misión sería defender a la sociedad bajo el imperio de la ley. Llegan a afirmar que es el único poder en la tierra, de manera que:

"La justicia, ni puede estar sujeta al poder ejecutivo, ni a las votaciones de los representantes, ni a las influencias de la prensa, ni a los manejos de los ambiciosos... el poder judicial que administra la justicia, ni puede estar sujeto a una real orden, ni puede depender del capricho que cambia con frecuencia el personal de los sillones dorados; los que esto pretenden, los que quieren que el poder judicial venga a ser un orden de escala en la gobernación del Estado, descubren sin quererlo que no están bien con la rectitud de los tribunales... La magistratura, pues, es un verdadero poder, con facultades propias, exclusivas, que no pueden cercenársele sin usurpación; ni se le pueden negar sin peligro de la libertad civil de los ciudadanos".

Facultades que encontramos ínsitas en la potestad de aplicar las leyes en los procesos judiciales. De manera que los tribunales deberian hacer respetar la ley, para hacerse respetar ellos mismos, pero siempre atemperándose a la legislación establecida. El derecho vigente -el derecho antiguo español- ofrecía garantías suficientes y, singularmente, "la independencia de los tribunales en sus fallos", pues sin ella no podría existir la administración de justicia por ser "la primera cualidad que el poder judicial debe sostener para merecer este nombre con todas

98 Cuya concreción figura en sus arts. 84 a 87. Proyecto de ley sobre arreglo y organización de los tribunales, leido en el Senado por el señor ministro de Gracia y Justicia en la sesión del dia 7 de enero de 1842 (Diarios de las sesiones de las Cortes. Senado. Legislatura 1841-42, Imprenta Nacional, Madrid, 1842, tomo único, $\mathrm{n}^{\circ} 4$, sesión de 7 de enero de 1842 , p. 29 y apéndice primero).

99 Ocupa las páginas 137-145 y 329-351 [con error de numeración] del tomo IV de la serie cuarta, aunque la segunda parte se centra en la crítica a la posición moderada de Alejandro Oliván, defensor del orden judicial, expuesta en la sesión del Congreso de los Diputados el 3 de diciembre de 1844 durante la discusión del proyecto de Constitución. La redacción y el tono de la segunda parte no es tan vehemente en la defensa del poder judicial, si bien el objetivo era propugnar su independencia: "llámese a la institución judicial poder, o lo que se quiera, respétese siempre su absoluta independencia, y no veamos el funesto ejemplo de que aquella prensa que con justicia ha proclamado la independencia de aquel poder, hoy acuse a los tribunales y quiera sujetarlos a influencias que en otro tiempo no muy lejano rechazaba". Aunque no figura la firma, en el tomo primero de la serie cuarta de dicha revista, correspondiente también a dicho año, figuran en la portada los nombres de Joaquín Francisco Pacheco, Pascual Fernández Baeza y Vicente Hernández de la Rúa. No parece que su autor fuera el primero, a juzgar por las afirmaciones que había manifestado con anterioridad y que figuran en sus Estudios de lejislación y de jurisprudencia, Viuda de Jordán e hijos, Madrid, 1843, pp. 220-221. Más parece que su redactor fuera el tercero, si cotejamos esas páginas con sus Lecciones de Derecho español, Salvador Albert, Madrid, 1838, tomo I, pp. 25-33, y tomo III, pp. 1-5. 
sus consecuencias" y cumplir sus fines, "y no como quiera una dependencia ficticia y de ningún resultado, como la en que ha existido de algunos años a esta parte". De conseguirse, seria respetada por los demás poderes y garantida por la sociedad. Planteamientos que sirven para adentrarse en la parte orgánica:

"Para conseguir esta independencia, aparece como primera cuestión la del nombramiento de los individuos que han de componer esta rueda politica que forma parte de la máquina del Estado, pues no puede negarse que el nombramiento del personal sujeta en cierto modo a los nombrados a una dependencia contraria a los principios de justicia e imparcialidad que en este ramo más que en otro alguno debe resplandecer a los ojos de la nación. Esta cuestión de suyo dificil, no está aún resuelta en nuestra organización politica, pues sin embargo de los reales decretos $y$ proyectos de ley que hemos visto aparecer de cuando en cuando, permanece todavia el poder judicial con desdoro de si mismo y con mengua de la cultura de nuestra edad, supeditado y sujeto a la clemencia ministerial".

Una dependencia ministerial que conduce a otro asunto: "consignar o depurar si los jueces están comprendidos en la clase de funcionarios que generalmente se llaman empleados". El autor o los autores de estas interesantes reflexiones rechazan la idea, y manifiestan que también debería hacerlo la Magistratura. Asunto terminológico nada baladí, pues "tal vez sea la única causa de los muchos agravios que están sufriendo". Y no podía considerárseles empleados públicos, porque "constituyen un poder del Estado; un poder libre, que no recibe inspiraciones sino de la ley, y cuando en desempeño de sus augustas funciones ordenan la forma de los procedimientos o pronuncian sus juicios, no trabajan por el Gobierno ni para el Gobierno", solo se limitan a aplicar la ley. El cotejo resultaba obvio: si los diputados de la nación no eran empleados, tampoco podrian serlo los que formaban "otro poder público también y exclusivo". Una diferencia entre empleados y jueces que se manifestaba por las atribuciones de unos y otros. En esta distinción no repercutiria el nombramiento regio, pues este "tampoco constituye empleo... le constituyen las atribuciones... y la ley que representa la soberania puede delegar estas o las otras funciones en los individuos o corporaciones que le parezca". La conclusión, en este punto, era que "la existencia pues del poder judicial no procede del nombramiento de los individuos que lo componen", remitiéndose ahora a la designación regia de los senadores para fundar este razonamiento. Entonces, ¿quién debería intervenir en el nombramiento? Modelo se habia propuesto, aunque fuera objeto de crítica: "El proyecto de ley de 7 de enero de 1842 confiaba al Tribunal Supremo de Justicia la facultad de proponer en terna que podría elevarse hasta el cuádruplo, para todos los cargos del poder judicial; la extensión de la propuesta desvirtuaba el acierto con que se encomendaba al Supremo Tribunal de la nación tan importante facultad". El planteamiento de los autores de este artículo era obvio:

"Los individuos del poder judicial deben ser nombrados por el mismo poder de que forman parte, no en terna sino absolutamente, y este nombramiento corresponde de derecho al Tribunal Supremo de la nación, a quien muy acertadamente confió la propuesta el proyecto de ley que hemos citado".

Pretensión que se enmarcaba en una separación de poderes, de aislamiento "de todo roce político" y sustentado en la defensa de la ley -que por cierto no lo 
regulaba-, al margen asimismo de las discusiones parlamentarias ${ }^{100}$. Frente a la ductilidad de la meritocracia politica, entendian que "el poder judicial en cuerpo... ofrece más calma, más madurez en las deliberaciones, más probabilidades de acierto en las resoluciones... confiéresele, pues, el alto cargo de nombrar todos sus individuos y habremos dado un gran paso en la carrera de las mejoras sociales". Postura que no buscaba "emancipar absolutamente al poder judicial de las relaciones convenientes que deben mediar entre el mismo y los demás poderes, particularmente el confiado a los ministros de la Corona". Por ello, entendian que al ejecutivo le incumbía una inspección superior para cuidar de que se administrara cumplidamente la justicia, con una importante limitación: "es muy bastante el que el Tribunal Supremo a quien se confiara el nombramiento comunique al Gobierno los que hiciere, solo para su conocimiento y efectos convenientes", permitiendo incluso intervenir al ministerio fiscal en este procedimiento.

Ante la imposibilidad de configurar legalmente un poder judicial orgánicamente independiente, se continuaba defendiendo su existencia desde la perspectiva funcional. Es conocido el discurso de apertura del año judicial pronunciado por Pedro Gómez de la Serna en 1869, cuando desempeñaba la presidencia del Tribunal Supremo. Un discurso del que es habitual encontrar algunos pasajes entresacados del contexto y omitidos otros. El título que le dio ya es de por sí significativo: Del Poder judicial, de sus relaciones con los demás poderes $y$ de las condiciones $y$ deberes de los que lo ejercen ${ }^{101}$. Después de repasar avatares históricos y opiniones moderadas, se pregunta: “¿la institución judicial, tal como está definida en la Constitución, es un verdadero poder? ¿Acaso por una de esas contradicciones que a veces se encuentran en las leyes, aun cuando estén bien redactadas, se da a los tribunales una calificación que en realidad, atendidas sus atribuciones, no les corresponde?”. De acuerdo con el texto constitucional que permitía a los tribunales no aplicar los reglamentos generales, provinciales y locales cuando no fueran conformes a las leyes, el poder judicial defendería su competencia y resistiria en este punto la invasión del poder ejecutivo, a pesar de que aquel "nunca obra activamente, nunca adopta medidas de carácter general" por cuanto le corresponda a este último. Su argumentación va más allá, cuando plantea que:

"Si, pues, el poder ejecutivo y su más alta expresión, el rey y sus ministros, cualesquiera que sean sus opiniones respecto a la justicia o injusticia de los fallos, tienen no solo que respetarlos, sino coadyuvar necesaria, indeclinablemente a su

100 "En el poder judicial -continúan- ni cabe ni puede admitirse la máxima de que cambiando el Gabinete deben cambiar todas las manos que dirigen la gobernación del Estado para amoldarse a la nueva marcha que adopte el Ministerio; el poder judicial que siempre es uno, inalterable, impasible como la ley, nada tiene que ver con la marcha del Gabinete, y como hemos dicho más arriba, aunque no tuviese con el Ministerio relaciones algunas cumplirá siempre con su deber, si tiene a la vista los códigos, y entiende el derecho. La administración de justicia, que ni es cuestión de Gabinete, ni asunto de los partidos, ha de permanecer siempre viva, perenne, duradera en la sociedad, y esta perpetuidad indispensable para la existencia de las naciones, no se consigue, mas se destruye con la movilidad de los individuos que han de administrarla, se aniquila completamente si el Ministerio persistiese en la pretensión de nombrar por sí a funcionarios que no deben depender de su voluntad discrecional". Idem.

101 Puede consultarse en Revista General de Legislación y Jurisprudencia, tomo XXXV, 1869, pp. 145-162. 
ejecución, sin poder resistir ni demorar... ¿cómo puede decirse que la institución judicial no es un poder verdadero, sino una manifestación del ejecutivo? No: la institución que tiene existencia propia; que ejerce funciones propias que ningún otro poder puede usurpar... es un poder independiente de los otros poderes. Aunque la Constitución no lo dijera, la lógica supliría su silencio"102.

A continuación, rebate los argumentos de quienes desvirtuaban la calificación de tal poder, es decir, que la justicia se administraba en nombre del rey y que a éste correspondia el nombramiento de jueces y magistrados. Con referencia a este último aspecto plantea que, si tal postura valiera, "debería decirse que el poder legislativo residia en los electores, no en las Cortes, y que también en los electores residia el poder ejecutivo y aun el judicial en las repúblicas en que el sufragio, ya universal, ya limitado elevan a la presidencia y a la magistratura a los ciudadanos que más llenan sus aspiraciones". Pero aquí, quizá, cabría oponer una objeción: una cosa es el ejercicio de la potestad, y otra bien diferente que los órganos que desempeñaron tal potestad llegaran a constituir orgánicamente en todos los casos un poder. El propio Gómez de la Serna reconoce, explícita e implícitamente, que en lo orgánico el vértice judicial se sitúa en el rey, cabeza del poder ejecutivo. Seguimos, por tanto, bien entrado el siglo XIX con rémoras del absolutismo monárquico por mucho que en la literalidad constitucional y normativa se hable del poder judicial. Moderados o progresistas, conservadores o liberales coincidian sustancialmente en ello, con independencia de las calificaciones terminológicas empleadas: orden o poder.

Con el antecedente fallido de 1842, hubo otro intento normativo por erigir orgánicamente tal poder judicial al establecer como institución clave para el gobierno de la administración de justicia al Tribunal Supremo. Pronto se advirtió la imposibilidad manifiesta de llevar a buen puerto esta iniciativa. En febrero de 1873 se presentaron nuevos planteamientos, sustentados en ideas progresistas que no encajaban bien en las estructuras estatales y en el pensamiento político del momento. Se buscó erigir un verdadero poder judicial, con una estructura propia a partir de los órganos existentes, aunque se mantuvieran algunas de las atribuciones del Gobierno sobre aquel, e independiente de lo orgánico. Nicolás Salmerón fue el adalid de semejante propuesta, de nuevo hecha por la vía de decreto y no mediante ley. Se pretendió que recayera en el Tribunal Supremo la representación de este poder, por ser la cúspide de la estructura institucional de la administración de justicia. De este modo, siendo la cúspide judicial en cuanto a lo procesal, se convertía a un tiempo en vértice de la pirámide orgánica, pues buena parte del procedimiento para la designación, traslado y separación de los jueces quedaba entre sus atribuciones. La falta de los medios precisos para que

102 Años antes había manifestado que "los jueces constituyen un poder público, que si bien dimana del ejecutivo, es independiente de él en el ejercicio de sus atribuciones" (Pedro Gómez de la Serna y Juan Manuel Montalbán, Elementos de Derecho civil y penal de España, Vicente de Lalama, Madrid, 1846, $3^{\text {a }}$ ed., tomo III, p. 13). Por el contrario, Donoso Cortes ya había expresado que, si bien los jueces eran el más firme apoyo del Estado, "no por eso constituyen un poder, puesto que no puede concebirse la idea del poder, si no se la asocia con la idea de la actividad, ni la actividad puede concebirse en el poder, si esa actividad no es espontánea, y si al realizarse no se formula en preceptos" (Principios constitucionales aplicados al proyecto de Ley fundamental, presentado a las Cortes por la Comisión nombrada al efecto, Compañia Tipográfica, Madrid, 1837, p. 43, texto reproducido, por ejemplo, en Obras de don Juan Donoso Cortés, Tejado Editor, Madrid, 1854, tomo I, p. 325). 
desarrollara esta facultad fue un obstáculo insalvable. Aspecto al que algunos agregaron las circunstancias politicas y de acceso de quienes en ese momento integraban la Judicatura y la Magistratura. A mayor abundamiento, se temia que si un poder al que se le encomendaba juzgar y hacer ejecutar lo juzgado, asumia atribuciones en la designación y movimiento de jueces y magistrados, podia convertirse en un poder omnimodo, imposible de ser controlado por los otros dos poderes, singularmente desde el ejecutivo ${ }^{103}$.

Hablar, por tanto, de división de poderes durante la etapa liberal en España, a pesar de la literalidad de sus textos constitucionales ${ }^{104}$, incluidos los más progresistas, es apartarse de la realidad en la que se desenvolvieron, entre otras razones, por la delegación legislativa, la vigencia de disposiciones normativas de rango infralegal o la peculiar aplicación de las previsiones constitucionales en cuanto a los principios que configuraban este pretendido poder judicial. Podemos simplificar esta visión para hacerla más comprensible. Si identificamos el poder ejecutivo con el rey y sus ministros, o en la práctica con estos últimos; y hacemos lo propio con el legislativo y las Cortes o ambos cuerpos colegisladores -Congreso de los Diputados y Senado; resultará, en fin, que no podemos hacer lo mismo con el Tribunal Supremo. ¿Podremos identificar el poder judicial con el medio millar de jueces de primera instancia, el centenar largo de magistrados de las Audiencias territoriales y sus homónimos del Tribunal Supremo? No. Entre otras razones porque no podemos encontrar un órgano que tanto en lo funcional como en lo orgánico represente u ostente la identificación unitaria de ese pretendido poder. Puede oponerse a esta afirmación que el art. 36 de la Constitución de 1869 declaraba que: "Los Tribunales ejercen el poder judicial"105. ¿El Tribunal Supremo con las Audiencias territoriales? Si lo tomamos en términos genéricos,

103 Me refiero al decreto del ministro de Gracia y Justicia Nicolás Salmerón, de 8 de mayo de 1873: “... en ningún caso debe restaurarse la antigua involucración del Poder judicial con el Ejecutivo, de cuya tutela urge por completo emanciparlo, no solo en el ejercicio de su autoridad, sino también en el nombramiento e investidura de sus representantes... Profunda reforma debe sufrir esta Ley, si ha de afirmarse la plena independencia del Poder judicial como un verdadero régimen republicano exige, y si ha de constituirse como un órgano sustantivo y libre de esta capital función del Estado de concierto con la soberanía de la Nación, de la cual deben emanar directamente todos los poderes públicos, acabando con el perturbador predominio que hasta ahora viene ejerciendo el Ejecutivo por triste herencia de la institución monárquica" (Gaceta de Madrid de 9 de mayo). En su consecuencia, se acordaba la inaplicación de la Ley orgánica provisional de Poder judicial de 1870 por vía de decreto alegando, entre otros motivos, la incongruencia entre lo establecido en dicha ley y la organización antigua de los tribunales. El decreto de 14 de enero de 1874 derogó el anterior, exigiendo el ministro de Gracia y Justicia que el Tribunal Supremo le remitiera los expedientes sobre jueces que tuviera "para resolverlos con sujeción a las prescripciones de la Ley sobre organización del poder judicial" (art. 2), pues el Gobierno pretendia recobrar el control del personal de dicho poder. Asunto que he abordado con mayor extensión en Inamovilidad, interinidad e inestabilidad, op. cit., pp. 312-326.

104 Para las interpretaciones que cabe dar a esta tiara -que no siempre lo fue- de poderes y su alcance en diferentes textos constitucionales, americanos y europeos, Bartolomé Clavero, El orden de los poderes. Historias constituyentes de la trinidad constitucional, op. cit..

105 No está de más recordar la R.O. de 19 de agosto de 1834 en la cual la reina María Cristina utilizaba esta misma expresión, aunque con carácter más genérico: "Deseando la Reina Gobernadora que todos los que ejercen el poder judicial vivan con el decoro e independencia necesaria para la recta administración de justicia..." (Gaceta de Madrid de 20 de septiembre). Cierto que las circunstancias y esencia politica de uno y otro texto fueron diferentes, pero no la expresión empleada. Las cursivas son mías. 
quizá, pero ello supondría situar en un plano de igualdad a los tribunales ordinarios territoriales y al único tribunal ordinario estatal, lo cual no parece muy adecuado. En el término tribunales, ¿se incluirian los jueces de primera instancia? La respuesta, en mi opinión, es positiva106. Lo llamativo es que la redacción literal de los dos artículos precedentes puede conducir a mayor confusión. El art. 34 determina que "la potestad de hacer las leyes reside en las Cortes", limitándose el rey a sancionar y promulgar. Mientras que el art. 35 dispone que "el poder ejecutivo reside en el rey, que lo ejerce por medio de sus ministros". O sea, que en su literalidad las Cortes tienen potestad, mientras que el rey con sus ministros y los tribunales tienen poder. La duda se puede resolver a primera vista porque el Título II tiene la rúbrica Del Poder legislativo, el cuarto Del Rey y el séptimo Del Poder judicial ${ }^{107}$. A mi juicio, fue la Constitución de 1812 la que mejor determinó la realidad constitucional que seguiria:

Art. 15. La potestad de hacer las leyes reside en las Cortes con el Rey.

Art. 16. La potestad de hacer executar las leyes reside en el Rey.

Art. 17. La potestad de aplicar las leyes en las causas civiles y criminales reside en los tribunales establecidos por la ley ${ }^{108}$.

106 "Art. 91. A los tribunales corresponde exclusivamente la potestad de aplicar las leyes en los juicios civiles y criminales". Creo que hay que entender incluido en dicho vocablo juzgados y tribunales, aunque los preceptos siguientes diferencian magistrados y jueces. Sobre la inclusión en dicho término del tribunal del jurado, véase Diarios de Sesiones de las Cortes Constituyentes, Madrid, 1870, tomo IV, sesión de 22 de mayo de 1869, pp. 2245-2246. El art. 76 de la Constitución de 1876 parece decantarse en el título IX, De la administración de justicia, por aquella solución: "A los tribunales y juzgados pertenece exclusivamente la potestad de aplicar las leyes en los juicios civiles y criminales". Sobre la rúbrica del título, consúltese lo manifestado por Manuel Alonso Martínez, a la sazón ministro de Gracia y Justicia, en la sesión de 27 de marzo de 1882, pues según él la misma fue adoptada en aras del consenso constitucional y en contra de su criterio, pero defendió que "se mantuvo el art. 76, en el cual se habla de la potestad exclusiva; y si la potestad exclusiva no es poder, venga Dios y véalo" (Diarios de sesiones de Cortes. Congreso de los Diputados. Legislatura 1881-1882, Viuda e hijos de J.A. Garcia, Madrid, 1882, tomo VI, n 90 , p. 2374). Una parte del debate se remite al debate constituyente de la sesión de 22 de mayo de 1876 (Diarios de sesiones de Cortes. Congreso de los Diputados. Legislatura 1876-1877, Viuda e hijos de J.A. Garcia, Madrid, 1877, tomo III, nº6, pp. 1647-1653).

107 Aunque también se negara su existencia, o más bien se afirmara su dependencia. En este sentido, cuando se discutía el precepto que se convertiria en el art. 94, de acuerdo con el cual "el Rey nombra a los magistrados y jueces a propuesta del Consejo de Estado y con arreglo a la ley orgánica de Tribunales", el diputado Gonzalo Serraclara mantuvo que, al depender todo el personal judicial del citado cuerpo, desaparecería por completo la desmembración entre el poder ejecutivo y el judicial, por cuanto dicho Consejo dependia del primero, de modo que "tendremos reunidos en una sola mano el poder ejecutivo y el poder judicial" (Diarios de sesiones de las Cortes Constituyentes, tomo IV, $\mathrm{n}^{\circ} 81$, sesión de 24 de mayo de 1869, p. 2280).

108 Aclaremos algunos vocablos a partir del Diccionario de la lengua castellana compuesto por la Real Academia Española, Viuda de don Joaquín Ibarra, Madrid, 1791 (3 ${ }^{a}$ ed.). Residir. "2. Se aplica también a las cosas no materiales, y vale estar". Potencia: 2. "La autoridad, facultad, o poder que uno tiene para executar, mandar y disponer de alguna cosa. Potestas". Potestad: "El dominio, poder, jurisdicción, o facultad que se tiene sobre alguna cosa. Potestas". Poder. "Tener expedita la facultad, o potencia de hacer alguna cosa. 2. Tener dominio, autoridad, o manejo. 8. El dominio, imperio, facultad y jurisdicción que uno tiene para mandar, o executar alguna cosa. Facultas, potestas". Hay que esperar a la edición de $1843\left(9^{\mathrm{a}}\right)$, para poder leer en el término Poder. "Ejecutivo. En los gobiernos representativos el que tiene a su cargo gobernar el Estado y hacer observar las leyes. Judicial. El que ejerce la administración de justicia. Legislativo. Aquel en que reside la potestad de hacer y reformar 
En primer lugar, no habla de poderes, sino de potestades, que hace recaer en los órganos que enumera y concreta en los dos primeros casos, pero que deja en un halo de indeterminación en el tercero, pues la ley diría ${ }^{109}$. En segundo lugar, porque encuentro que está más en consonancia con el término puissance que es el que empleó Montesquieu ${ }^{110}$, y, más aún, con la Constitución francesa de 1791, puesto que si de la nación derivan todos los poderes (tít. III, art. 1: "La Nation, de qui seule émanent tous les pouvoirs, ne peut les exercer que par délégation"), la consecuencia directa es que "le pouvoir judiciaire est délégué à des juges élus à temps par le peuple" (tít. III, art. 5), como el legislativo lo era a la Asamblea. Es decir, no es que los jueces constituyeran un poder judicial, sino que ejercian por delegación el poder judicial que era propio de la nación (titularidad), a la que pertenece esencialmente la soberanía, aunque en términos normativos tal delegación y su ejercicio ínsito devenía de la declaración constitucional que hacía la nación. La deformación terminológica devino en la conclusión de que existía un poder judicial compuesto, indeterminadamente, por los tribunales y jueces establecidos por la ley, en abstracto, y que, salvando la vigencia de los Reglamentos aprobados por las Cortes gaditanas en octubre de 1812 y marzo de 1814, tardó décadas en ser promulgada. En todo caso, los constituyentes gaditanos tuvieron claro que no existía ningún poder judicial, pero sí el ejercicio de una potestad delegada:

leyes". Sobre la tradicional jurisdiccional del concepto de potestas y su proyección teórica constitucional, Bartolomé Clavero, El orden de los poderes, op. cit., pp. 26-27, 124-127 y 268.

109 Las rúbricas de los títulos, además, no concuerdan con tal división de potestades: III. De las Cortes. IV. Del Rey. V. De los Tribunales y de la administración de justicia en lo civil y en lo criminal. Sobre la crítica a esta configuración constitucional y, sobre todo, a su interpretación historiográfica, Bartolomé Clavero, El orden de los poderes, op. cit., pp. 265-289. Parece inclinarse por su existencia orgánica Ignacio Fernández Sarasola, quien señala que la Constitución, en primer lugar, atribuía de la titularidad de la soberanía a la nación, para después dividir "el ejercicio de esa soberanía entre diversos órganos (división de poderes)" ("La división de poderes en la historia constitucional española”, Fundamentos. Cuadernos monográficos de Teoría del Estado, Derecho público e Historia constitucional, n 5, 2009, pp. 169-202).

110 "Il y a dans chaque État trois sortes de pouvoirs: la puissance législative, la puissance exécutrice des choses qui dépendent du droit des gens, et la puissance exécutrice de celles qui dépendent du droit civil... La puissance de juger ne doit pas être donnée à un sénat permanent, mais exercée par des personnes tirées du corpos du peuple...". Según Pierre Richelet, Dictionnaire de la langue françoise, ancienne et moderne, Freres Duplain, Lyon, tomo III, 1759, p. 298: "Puissance [Potestas, potentia] Pouvoir, autorité, crédit. (Une grande puissance. Une puissance considérable. Avoir beaucoup puissance. La Toute-puissance de Dieu). On dit, qu'une femme est en puissance de mari, et qu'un fils est sous la puissance paternelle jusqu'à ce qu'il soit émancipé". En este sentido, se ha sostenido que pouvoir y puissance, son términos prácticamente sinónimos en francés, pero dificiles de distinguir en otras lenguas, de manera que el primero "se manifiesta o expresa mediante su puissance... Un poder tiene potestad para hacer algo", en palabras de Demetrio Castro Alfin en la edición Montesquieu. El espiritu de las leyes, Istmo, Madrid, 2002, p. 55. Desde un punto de vista jurídico, resulta diferente la interpretación aportada por Santi Romano, en un conocidísimo pasaje, pues considera que desde "la terminología legislativa podría acaso pensar que habria que hablar más propiamente de potestades cuando su titular aparece investido de una autoridad, sea ella de derecho público, sea de derecho privado, mientras que cuando falta este elemento de la autoridad y de la consiguiente posición de superioridad o supremacia, se ha usado más frecuentemente la palabra poder" ("Poderes, potestades", en Fragmentos de un Diccionario jurídico, Ediciones Jurídicas Europa-América, Buenos Aires, 1964, p. 332). 
“... el arreglo de la potestad judicial en toda la extensión que comprehende la administración de justicia en lo civil y criminal exige mucha escrupulosidad y circunspección... La sabia distribución que V. M. (refiriéndose a las Cortes) ha hecho del exercicio de la potestad soberana en su memorable decreto de 24 de setiembre, ha facilitado a la Comisión el fixar los cánones que han de arreglar en adelante el importantísimo punto de la potestad judicial. La Comisión, según el plan que se ha propuesto, delega esta autoridad a los tribunales, comprehendiendo baxo este nombre, no solo a los cuerpos colegiados, sino también a los jueces ordinarios, que en rigor constituyen tribunal, quando acompañados de los ministros que las leyes señalan, exercen el ministerio de la justicia... Aunque la potestad judicial es una parte del exercicio de la soberanía delegada inmediatamente por la Constitución a los tribunales, es necesario que el rey, como encargado de la execución de las leyes en todos sus efectos, pueda velar sobre su observancia y aplicación. El poder de que está revestido (en referencia al rey), y la absoluta separación e independencia de los jueces, al paso que forman la sublime teoria de la institución judicial... Delegada por la Constitución a los tribunales la potestad de aplicar las leyes, es indispensable establecer, para que haya un sistema, un centro de autoridad en que vengan a reunirse todas las ramificaciones de la potestad judicial..."111.

En cuanto que, constitucionalmente, el nombramiento de jueces y magistrados corresponde a quien ejerce el poder ejecutivo, creo que debe rechazarse la afirmación de que, durante los debates gaditanos, existieron "diputados que se refieren con naturalidad a la Organización judicial denominándola Poder Judicial, sin que nadie les contradiga". Como también que "la proclamación de que existe un Poder Judicial entendido como el conjunto de los Tribunales de Justicia aparece en los arts. 17 y 242, de análogo contenido dispositivo" 112. Dichos preceptos lo único que disponen es en quién reside la potestad -atribución si se quiere- de aplicar las leyes en las causas civiles y criminales, es decir, en los tribunales, con una indeterminación tal -por ejemplo, ¿se incluyen los castrenses y eclesiásticos?- que no permite interpretar la existencia de un poder (orgánico) judicial, que es a lo que se refiere el constitucionalista que tal afirma. En mi opinión, cuando los diputados emplean la expresión "poder judicial" se refieren a su potestad funcional y no a su configuración orgánica y funcional.

Como el asunto no es pacífico, pueden plantearse dudas, ya que encontramos expresiones en las Cortes gaditanas tales como "individuos del poder judicial" (Antillón) o "entregarlo después al poder judicial" (Antillón), que favorecen la idea de un poder judicial constituido orgánicamente ${ }^{113}$. Los Decretos

111 Texto datado el 6 de noviembre de 1811 e inserto en Continuación del proyecto de Constitución politica de la Monarquia española presentado a las Cortes Generales y Extraordinarias por su Comisión de Constitución. Contiene la parte relativa a la potestad judicial, Imprenta Real, Cádiz, 1811, pp. 4-5 y 7-8. Pasaría al Discurso preliminar a la Constitución, que es por donde habitualmente se cita. Los pasajes resaltados en redonda son míos.

112 Postura defendida por Óscar Alzaga Villamil, “La justicia en la Constitución de 1812”, Teoria y Realidad Constitucional, $n^{\circ} 28,2011$, pp. 243-278, la cita en p. 256. Lo que sí debe negarse, a mi entender, es la "consagración plena del dogma de la independencia judicial", por cuanto el nombramiento de los juzgadores quedó retenido en el ejecutivo, y en modo alguno encomendada ni constitucional ni legalmente a un órgano judicial.

113 Diarios de las Cortes Generales y Extraordinarias, J.A. Garcia, Madrid, 1870, tomo VIII, ns ${ }^{\circ}$ 873 y 886, sesiones de 4 y 19 de junio de 1813, pp. 5418 y 5520. El diputado Melchor Marau 
de las Cortes de 9 de octubre de 1812 y de 13 de marzo de 1814 eluden los vocablos poder y potestad. En la exposición que precede al R.D. de 22 de septiembre de 1836 por el que se creaba la junta para el arreglo de tribunales y juzgados del reino, José Landero justifica su creación por cuanto como "depositarios de la vida, del honor y de la fortuna de sus semejantes, deben formar un poder separado e independiente" organizado sobre los principios de inamovilidad y responsabilidad de aquellos, aunque por faltar el Consejo de Estado, creaba dicha junta, entre cuyas misiones estaba la de "preparar asimismo la organización del poder judicial"114. Álvaro Gómez Becerra, como ministro de Gracia y Justicia, insistirá en la independencia del poder judicial y de los miembros que lo componian ${ }^{115}$. Indudablemente, los postulados progresistas defendian la existencia orgánica de un poder judicial. Así, Martín de los Heros afirmaba que "no aplicándose la palabra magistrados pura y exclusivamente a los individuos del poder judicial, me parece que debe sustituirse a ella la palabra jueces"116. El proyecto de 14 de marzo de 1842 sobre inamovilidad y responsabilidad de los magistrados y jueces, al tiempo que estaba presentado otro de ley orgánica "de los tribunales y juzgados", incidia en la calidades y requisitos "de todos los funcionarios del poder judicial", teniendo presente "el actual estado del personal del poder judicial"117. Las menciones más numerosas a los "dependientes del poder judicial" se encuentran en las resoluciones de los conflictos de competencias ${ }^{118}$.

En otras ocasiones encontramos duplicidad en la referencia. En una C. de 27 de mayo de 1841, el ministro José Alonso, por un lado, afirma que "el

hablaba del honor "de los individuos del poder judicial" (Diario de las sesiones de Cortes. Legislatura de 1822, J.A. Garcia, Madrid, 1872, tomo II, $\mathrm{n}^{\circ}$ 89, sesión de 18 de abril de 1822, p. 901). La Circular del Ministerio de Gracia y Justicia de 23 de octubre de 1841, determinaba que si los funcionarios estaban obligados a defender por las armas a la patria cuando lo dispusiera la ley, también afecta "a todo empleado en el poder judicial" que no estuviera exento (Gaceta de Madrid del 28 de octubre) El artículo referido que fue publicado en el Boletín de Jurisprudencia y legislación sostenía que "los individuos del poder judicial deben ser nombrados por el mismo poder de que forman parte" (IV, 1844, p. 143). En un artículo de un periódico de Barcelona y a propósito del movimiento de jueces que se había producido, se lamentaba de la facilidad de "despojar de la toga y poner en medio de la calle a un individuo el poder judicial" (El Faro Nacional, VI, 1858, 14 de septiembre, p. 288).

114 Gaceta de Madrid de 24 de septiembre de 1836.

115 DD. de 10 y 30 de octubre de 1840 (Gaceta de Madrid de 21 de octubre y 2 de noviembre). Gómez Becerra también alude a la "humillación de los individuos del Poder judicial" (Observaciones sobre el estado del poder judicial en España, op. cit., p. 60).

116 Diarios de sesiones de las Cortes Constituyentes. 1836-1837, J.A. García, Madrid, 1872, tomo V, $\mathrm{n}^{\circ} 199$, sesión de 17 de mayo de 1837, p. 3423.

117 Gaceta de Madrid de 22 de marzo de 1842. También se referirá a los "funcionarios del poder judicial" la exposición de motivos del R.D. de 3 de julio de 1863 sobre estadística judicial (Gaceta de Madrid de 8 de julio). En el discurso pronunciado por Espartero en la apertura de las Cortes el 3 de abril de 1843 se reconocía "el celo y la rectitud con que generalmente los tribunales y jueces administran la justicia, no obstante la imperfecta organización del poder judicial" (Gaceta de Madrid de 4 de abril).

118 Como simple muestra: "que en su consecuencia la Subdelegación exhortó en 13 de enero al intendente para que se inhibiese del conocimiento del asunto; que esta autoridad no accedió a la inhibición, porque en su sentir no es el poder judicial el que debe intervenir en la aplicación de la ley de 2 de setiembre de 1841" (Gaceta de Madrid de 1 de abril de 1852). 
magistrado y el juez deben ser tan impasibles como la ley misma: el poder que ejercen solo lo tienen por ella", pero, a continuación, sostiene que "todos los individuos del poder judicial" deberian redoblar sus esfuerzos para conseguir una administración de justicia digna ${ }^{119}$.

Pero son, sobre todo, los proyectos presentados hasta 1870 los que dan una idea más aproximada de lo que se pretendía regular, pues mayoritariamente omiten la expresión "poder judicial" y optan por referirse explícitamente en sus rúbricas a los tribunales o a la organización judicial ${ }^{120}$. Referencias que, si bien

119 Gaceta de Madrid de 30 de mayo de 1841. Encontramos menos concreción en Manuel Ortiz de Zúñiga, pues alude a que su propósito era "exponer las atribuciones del poder judicial, tal cual este se halla constituido", pero también se refiere a los tribunales "que ejercen la potestad judicial" (Biblioteca judicial. Parte tercera en que se contienen la organización y atribuciones de las Audiencias y del Tribunal Supremo de Justicia, Oficina de don Tomás Jordán, Madrid, 1840, tomo III, p. 195). En la Circular de la presidencia del Tribunal Supremo de 22 de junio de 1843, José Calatraveño, podemos leer: "El poder judicial puede contribuir eficazmente al sostenimiento de la Constitución, del Trono, de la Regencia y del orden público; los encargados de ejercer este poder..." (Gaceta de Madrid de 24 de junio). En la exposición de motivos de la Dictamen de la Comisión de las Cortes sobre las bases de la Ley orgánica de Tribunales de 14 de febrero de 1856, se puede leer: "Cuando los jueces ejercen funciones politicas o de la administración activa; cuando son agentes más o menos inmediatos del Poder ejecutivo, entonces peligra la independencia del Poder judicial, y con ella la justicia. Ni se concibe que haya funcionarios públicos a un mismo tiempo amovibles como agentes de la administración, e inamovible como jueces y magistrados" (Diario de sesiones de las Cortes Constituyentes, Viuda e hijos de J.A. García, Madrid, 1880, tomo XII, $\mathrm{n}^{\circ}$ 313, sesión de 15 de febrero de 1856, apéndice tercero, y tomo $\mathrm{XV}, \mathrm{n}^{\circ} 408$, sesión de 18 de junio de 1856 , apéndice quinto). La base $25^{\mathrm{a}}$ de este último texto alude expresamente a una futura ley "de organización judicial”.

120 Proyecto de la Junta de jefes del Ministerio de Gracia y justicia "sobre administración de justicia" (1837), Proyecto del ministro Salvato "sobre administración de justicia" (Diarios de sesiones de Cortes. Congreso de los Diputados. Legislatura 1836-37, J.A. Garcia, Madrid, 1870, tomo IV, n 327, sesión de 2 de octubre de 1837, pp. 6404-6405), Proyecto "sobre administración de justicia" para el desarrollo de la Constitución (Diarios de las sesiones de Cortes. Congreso de los Diputados, Legislatura de 1837-38, J.A. Garcia, Madrid, 1874, tomo IV, n 167, sesión de 7 de junio de 1838, apéndice segundo), Proyecto de ley sobre arreglo y organización de los tribunales, leído en el Senado por el señor ministro de Gracia y Justicia en la sesión del dia 7 de enero de 1842 (Diario de las sesiones de Cortes. Senado, Legislatura de 1841-42, tomo único, n 4, sesión de 7 de enero de 1842, apéndice primero), Proyecto de ley constitutiva de los tribunales definitivamente redactado y aprobado por la Comisión de Códigos (Gaceta de Madrid de 10 de julio de 1846), Real decreto previniendo que para la próxima legislatura se presentará un proyecto de organización judicial (Gaceta de Madrid de 9 de octubre de 1847), Proyecto de Ley sobre organización, competencias y facultades de los Tribunales del fuero general presentado por el ministro de Gracia y Justicia (Gaceta de Madrid de 7 a 15 de marzo de 1848), Proyecto de ley de organización, competencia y facultades de los tribunales del fuero general de la Comisión de Códigos de 21 de diciembre de 1847 (Gaceta de Madrid de 7 a 15 de marzo de 1848), Proyecto de ley constitutiva de los Tribunales de fuero común, leído por el Sr. Ministro de Gracia y Justicia en la sesión del Senado del sábado 23 de Noviembre de 1850 (Gaceta de Madrid de 3 de diciembre), Proyecto de ley constitutiva sobre organización de Tribunales del fuero común (Gaceta de Madrid de 25, 26 y 28 de noviembre y 1 de diciembre de 1853), Proyecto de reformas a la Ley Orgánica de los Tribunales presentada a las Cortes en la última legislatura, redactado por el presidente de la Sección de procedimientos de la Comisión de Códigos, Manuel García Gallardo (Gaceta de Madrid de 4, 5 y 10 de enero de 1854), Proyecto de ley constitutiva de los juzgados y Tribunales del fuero común, aprobado por secciones reunidas de procedimiento civil y criminal de la Comisión de Códigos (Gaceta de Madrid de 1, 2, 3, 5, 6, 7, 8, 9, 10 y 11 de junio de 1854), Real decreto disponiendo que la comisión encargada para la formación de la ley orgánica de Tribunales (Gaceta de Madrid de 10 de agosto de 1855), Proyecto de Ley presentado a las Cortes en 22 de octubre de 1855 por el Sr. Ministro de Gracia y Justicia, Real Decreto para que la Comisión de Códigos se dedique a la Ley orgánica de Tribunales (1858), Proyecto de Ley de bases de 
aparecen en períodos dominados por el moderantismo, no puede reducirse en exclusiva a ellos, pues encontramos también remisiones a una comisión encargada de redactar "el proyecto de sobre sobre organización judicial", entre cuyos objetivos estaba el de fijar "en sus verdaderos limites al poder judicial, estrictamente clasificado y definido" para que los jueces conquistaran el lugar que debían ocupar en la administración de justicia en lo criminal ${ }^{121}$. Durante décadas, desde las instancias del poder ejecutivo, no se pretendió regular orgánicamente el poder judicial sino la estructura orgánica de los tribunales, lo cual, desde la teoria política de la división o separación de poderes, implicaba una manifiesta negación de la existencia de un tercer poder. Incluso cuando formalmente se promulga Ley provisional del poder judicial en septiembre de 1870 hallamos que en su articulado no se menciona al "poder judicial", pues las referencias, como por ejemplo la del art. 2, lo son a jueces y tribunales a quienes corresponde "la potestad de aplicar las leyes en los juicios civiles y criminales"122.

Siguiendo la línea de lo expuesto, también hallamos otras expresiones en sentido diferente, por ejemplo "podrá hacerlo en esta causa, en que ejerce el poder judicial" (Martinez de Villela)123. El D. de 14 de marzo de 1820 por el que se restablecian las Audiencias constitucionales "ejerciendo el poder judicial con arreglo a la Constitución y al reglamento de 9 de octubre de 1812"124. Ya he citado la R.O. de 18 de agosto de 1834 que alude "a todos los que ejercen en el día o entren en lo sucesivo a ejercer el poder judicial". Más extraño es encontrar

organización de Tribunales de 6 de abril de 1863 (Esposición de los motivos y fundamentos de las bases para las Leyes de organización de tribunales del fuero común y enjuiciamiento criminal, Ministerio de Gracia y Justicia, Madrid, 1863), Proyecto de Ley de organización de Tribunales presentado por el ministro de Gracia y Justicia el 6 de noviembre de 1863 (Diario de sesiones de las Cortes. Senado. Legislatura. 1863-64, Imprenta Nacional, Madrid, 1864, tomo I, $\mathrm{n}^{\circ} 3$, apéndice vigésimo), Proyecto de organización de Tribunales presentado por el ministro de Gracia y Justicia (Diario de las sesiones de Cortes. Senado. Legislatura de 1864-65, Imprenta Nacional, 1865, tomo I, $\mathrm{n}^{\circ} 5$, sesión de 7 de enero de 1865), Proyecto de organización provisional de Tribunales de la Comisión de Codificación (1868), Proyecto de bases para la organización de Tribunales presentado por el ministro de Gracia y Justicia (Diario de las sesiones de Cortes. Senado. Legislatura 1867-68, J.A. García, Madrid, 1868, tomo único, $\mathrm{n}^{\circ} 7$, sesión de 17 de enero de 1868, apéndice) y Ley señalando bases para la organización de los Tribunales (Gaceta de Madrid de 12 de abril de 1868). Referencias a todos ellos en Francisco Lasso, Crónica de la Codificación. I. Organización judicial, op. cit., passim.

${ }^{121}$ Circular del ministro de Gracia y Justicia de 5 de marzo de 1856 (Gaceta de Madrid de 7 de marzo).

122 Gaceta de Madrid de 15 de septiembre de 1870.

123 Diarios de las Cortes Generales y Extraordinarias, J.A. Garcia, Madrid, 1870, tomo VIII, $\mathrm{n}^{\circ}$ 924, sesión de 27 de julio de 1813, p. 5809. Ignacio Martínez de Villela habia alcanzado la magistratura del Consejo de Castilla y se mostró partidario del absolutismo. El diputado Romero sostenía que "como quiera que la administración de justicia no puede referirse a otros que a los magistrados o a los que ejercen el poder judicial" (Diario de las sesiones de las Cortes. Legislatura de extraordinaria (1822-1823), J.A. Garcia, Madrid, 1872, tomo I, nº 29, sesión de 31 de octubre de 1822 , p. 424. José Posada de Herrera detalla que "se llama jurisdicción prorrogada aquella que ejerce el poder judicial o el administrativo en su caso" (Lecciones de administración, op. cit., tomo I, p. 97).

124 Gaceta de Madrid, extraordinaria de 17 de marzo de 1820. 
menciones al ejercicio de la "potestad judicial"125, que por su reducido número se presentan como excepción a la regla general, que es el empleo de "poder judicial".

Existe otro aspecto que se ha destacado recientemente y que ahonda en la inexistencia orgánica del poder judicial durante el siglo XIX: el carácter personal de la inamovilidad, es decir, "no se concede al colectivo -a cualquiera integrado en la Judicatura- sino al individuo -a cada juez-, por lo que al no ser un principio abstracto sino una concesión personal, el control fue mucho mayor"126. Esta concesión, sin entrar en el procedimiento por el cual se verificaba, no se otorgaba por pertenecer al "poder judicial", sino por la autoridad ministerial.

Al hilo de lo anterior, ejercer el poder (potestad) no significa constituir un poder. De ahí que el art. 36 de la Constitución de 1869 deba entenderse en estos términos, es decir, los tribunales ejercen la potestad judicial, aunque no constituyen un poder orgánico, de modo que solo les corresponde la administración de justicia -aplicar las leyes en los procesos- en el ámbito civil y en el criminal por residir en ellos el ejercicio de dicha potestad ${ }^{127}$. Sin que en la práctica pueda mantenerse la literalidad de la afirmación de Montesquieu, según la cual "de los tres poderes que hemos hablado, el de juzgar es, en cierto modo, nulo" 128 , porque, aunque se limita a aplicar la ley, en la práctica no lo hace de modo mimético. Bien sabian los juristas, desde épocas anteriores, que en la ley no caben todos los supuestos que acaecen en la realidad tal y como en ella se regulan, de la ahí la coherencia de acudir a la discrecionalidad judicial para concretar la generalidad de la ley al caso individual.

El diputado moderado Manuel Danvila, durante la discusión de la Ley de bases que está en el origen de la Ley orgánica provisional del poder judicial, resumió lo que, entiendo, era el sentir del momento:

"Los derechos son el objeto de esa misma administración; su instrumento son los jueces y tribunales; los juicios sus medios y todo ello con el poder judicial forma ese conjunto armónico que se llama administración de justicia"129.

125 El conde de Toreno aludió a "la constitución dexa a los individuos que componen la potestad judicial en una casi absoluta independencia" (Diario de sesiones de las Cortes Generales y Extraordinarias, J.A. García, Madrid, 1870, tomo IV, $\mathrm{n}^{\circ}$ 521, sesión de 15 de marzo de 1812, p. 2919). El Secretario de Hacienda emplea la expresión "desde el momento que entrega los individuos a la potestad judicial" (Diario de las sesiones de Cortes. Estamento de Procuradores. Legislatura de 18341835, J.A. García, Madrid, 1867, tomo III, $\mathrm{n}^{\circ}$ 166, sesión de 10 de marzo de 1835, p. 1829).

126 Así lo he expuesto en Inamovilidad, interinidad e inestabilidad, op. cit., pp. 49 y 108.

127 Algunos se debatían entre su consideración o no como poder: "Aunque el aplicar las leyes en los casos civiles y criminales, o sea la administración de justicia, es una rama del tronco de la potestad ejecutiva, es tan importante, que se le considera como un tercer poder, y se ha creido por algunos necesario poner empeño en que no se confunda con los demás... Pero realmente la administración de justicia no es otra cosa que una delegación perpetua del poder ejecutivo a la magistratura, y esto es lo que se establece en el artículo a que este comentario se refiere, y en los pertenecientes al título VII, cuyo epígrafe es del poder judicial", en Constitución de 1869, y leyes orgánicas, municipal, provincial, electoral y de orden público, comentadas y relacionadas con nuestro Derecho vigente por una Sociedad de publicistas, El Puente de Alcolea, Madrid, 1870, p. 157.

128 Cito por la edición de Castro Alfin, Montesquieu. El espíritu de las leyes, op. cit., p. 250.

129 Diario de sesiones de Cortes. Congreso de los Diputados. Legislatura 1867-1868, J.A. Garcia, Madrid, 1868, tomo I, n. 41, sesión de 18 de marzo de 1868, p. 486. 


\section{LA OPORTUNIDAD DE REVISIONES CRÍTICAS}

Con el fin de terminar estas reflexiones, parece, pues, interesante replantearse la actuación del llamado poder legislativo, de las Cortes, en España durante el siglo XIX. Es cierto que el poder legislativo adquirió desde los postulados de Locke un papel central, pero eso no quiere decir dominante. Las Cortes aprobaban las leyes y el principio de legalidad constitucional estuvo presente en la teoría del sistema político-jurídico decimonónico. Pero la teoría jurídico-política fue desplazada por la práctica del poder ejecutivo y, en definitiva, por la partitocracia que vio en el legislativo un medio -no un poder- para conseguir hacerse con el Gobierno y, en definitiva, dominar el procedimiento legislativo y la aplicación de la ley, aunque durante décadas le bastó con emplear el decreto.

Al mismo tiempo, más allá de la literalidad de los textos constitucionales y legales, convendria obviar la existencia de un poder judicial, hasta décadas recientes, en cuanto poder organizado e independiente en lo orgánico del ejecutivo. Lo interesante se halla en la potestad judicial, que no pudieron ejercer en modo alguno los otros dos poderes. Sin olvidar, tampoco, que, junto a la aplicación de la ley en los procesos civiles y criminales, jueces y tribunales tuvieron asignadas otras atribuciones, en particular las fijadas en la normativa electoral, lo que redundaba en su actuación como agentes del ejecutivo, aspecto no siempre tenido en cuenta por la historiografia jurídica.

Un mejor conocimiento crítico de la actividad real en el ámbito de las potestades ejecutiva, legislativa y judicial durante el siglo XIX permitirá descubrir fundamentos de ciertos problemas que se han perpetuado hasta la actualidad en materia de administración de justicia, aunque ahora contemos con un poder judicial, si bien mediatizado por la influencia partidista. La lectura de lo que hasta ahora conocemos parece, por momentos, una descripción de situaciones planteadas hoy en dia, incluida la preponderancia real del poder ejecutivo sobre el legislativo, y el inusitado -en ocasiones, despiadado- interés por controlar desde aquel a los órganos de la administración de justicia.

Desde mi posición de ciudadano, la historiografia contemporánea permite ver reflejados rasgos de la historia judicial de la España decimonónica en la actual, asi como descubrir la permanencia de algunos problemas irresolutos desde entonces, sin duda, como apuntaba Pérez-Prendes, porque nos encontramos en un ciclo histórico incompleto, "lo que impone una constante revisión de la investigación producida, dado lo frecuente de la caducidad de las interpretaciones formuladas"130.

Enviado el (Submission Date): 07/01/2019

Aceptado el (Acceptance Date): 12/03/2019

130 José Manuel Pérez-Prendes, Historia del Derecho Español, Universidad Complutense, Madrid, 2004, tomo II, p. 1799. 